Federal Reserve Bank of Dallas

Globalization and Monetary Policy Institute

Working Paper No. 52

http://www.dallasfed.org/assets/documents/institute/wpapers/2010/0052.pdf

\title{
Financial Globalization, Financial Frictions and Optimal Monetary Policy ${ }^{*}$
}

\author{
Ester Faia \\ Goethe University Frankfurt \\ Kiel IFW \\ CEPREMAP \\ Eleni Iliopulos \\ PSE \\ University of Paris 1 \\ CEPREMAP
}

June 2010

\begin{abstract}
How should monetary policy be optimally designed in an environment with high degrees of financial globalization? To answer this question we lay down an open economy model where net lending toward the rest of the world is constrained by a collateral constraint motivated by limited enforcement. Borrowing is secured by collateral in the form of durable goods whose accumulation is subject to adjustment costs. We demonstrate that, although this economy can generate persistent current account deficits, it can also deliver a stationary equilibrium. The comparison between different monetary policy regimes (floating versus pegged) shows that the impossible trinity is reversed: a higher degree of financial globalization, by inducing more persistent and volatile current account deficits, calls for exchange rate stabilization. Finally, we study the design of optimal (Ramsey) monetary policy. In this environment the policy maker faces the additional goal of stabilizing exchange rate movements, which exacerbate fluctuations in the wedges induced by the collateral constraint. In this context optimality requires deviations from price stability and calls for exchange rate stabilization.
\end{abstract}

JEL codes: E52, F1

Ester Faia, Chair in Monetary and Fiscal Policy, Goethe-Universität Frankfurt am Main, Senckenberganlage 31, 60325 Frankfurt am Main, Germany. faia@wiwi.uni-frankfurt.de. Eleni Iliopulos, Paris School of Economics, University of Paris 1 Panthéon - Sorbonne, MSE, bureau 309, Bd L'Hôpital 75647, Paris CEDEX 13, France. 0033-0-1-44-07-82-65. Eleni.iliopulos@univ-paris1.fr. We gratefully acknowledge financial support from European Community grant MONFISPOL under grant agreement SSH-CT-2009-225149. We thank participants at the MONFISPOL Meeting held in Pairs and to the conference "Theory and Methods in Macroeconomics" for comments. The views in this paper are those of the authors and do not necessarily reflect the views of the Federal Reserve Bank of Dallas or the Federal Reserve System. 


\section{Introduction}

The last two decades have been characterized by an extraordinary wave of financial globalization often accompanied with persistent current account imbalances ${ }^{1}$. For many countries current account imbalances have been negatively related to booms in house price, mortgages and consumer credits and durable demand. Since a significant proportion of claims on consumers credit has been placed in the international markets, for many countries the boom in durable demand has been mainly financed with foreign lending ${ }^{2}$. Lending standards have been in general quite loose along several dimensions and overall they have been tied to collateral values, in a way that swings (upward or downward) in durable prices (particularly house prices) have determined the amount of lending ${ }^{3}$.

Against this background many central banks around the world have followed, explicitly or implicitly, inflation targeting or price stability polices without putting any weight on asset or durable prices and exchange rate movements. This is remarkable given that some countries had experienced significant exchange rate depreciations and asset price growth. We therefore ask whether the prescriptions for monetary policy change in an environment as the one described above.

To this purpose we lay down a DSGE small open economy model in which agents consume durable and non-durable goods ${ }^{4}$, supply labour services and finance consumption with foreign lending. The rest of the world is populated by infinite lived agents who behave as consumption smoothers. Total (net) lending is constrained by a borrowing limit and is secured by collateral in the form of durable stock, as the latter can be seized by lenders in the event of default. Due to imperfect monitoring only a fraction of this collateral can be pledged by lenders. The type of borrowing constraint considered is a collateral constraint on the line of Kiyotaki and Moore [46], Kocherlacota [48], Chari, Kehoe and McGrattan [23] among others. We further assume that durable goods provide utility services (see Davis and Heatcote [29], Miles [64], Iacoviello [41], Campbell

\footnotetext{
${ }^{1}$ Backus, Henriksen, Lambert, Telmer [5] show that among industrialized countries the US, the UK, Spain and Australia have run persistent current account deficits.

${ }^{2}$ See Bernanke [15] for a discussion of the link between global imbalances and house price booms. He noticed that countries whose current accounts have moved toward deficit have generally experienced substantial housing appreciation and increases in household wealth.

${ }^{3}$ The collateral policy practice adopted in the last two decades were quite risky as absence of any information on future income streams the availability of lending is heavily dependent on the market swings. In many occasions banks have renewed and replenished mortgages whenever the house price had gone up independently from the ability of the borrower to repay.

${ }^{4}$ We assume that only non-durable goods are tradable and are aggregated through Armington aggregator.
} 
and Hercowitz [19] and Monacelli [65]) and that durable investment is subject to adjustment costs, an assumption which allows to reproduce persistence in response to various shocks (see Topel and Rosen [83], Erceg and Levin [33]). In this model net asset accumulation is determined by the borrowing constraint and depends on the future value of collateral. The degree of financial globalization in this economy is captured by the parameter characterizing the sensitivity of foreign lending to the value of collateral, as a higher value relaxes the constraint on foreign lending. There are two production sectors in the domestic economy: the durable good sector and the nondurable goods sector. Firms in both sectors are monopolistic competitive and face Rotemberg [75] adjustment costs: this assumption is introduced to study non-neutral monetary policy and to compare alternative monetary policy regimes. Monetary policy is conducted by means of Taylor type rules.

Three results arise. First, we show that the net asset accumulation in this model is uniquely determined in the steady state and that it is saddle path stationary in a neighborhood of the steady state. A crucial assumption for this result is that foreign agents have higher discount rates than domestic lenders. In this case the domestic economy experiences a persistent current account deficit, as in equilibrium domestic residents behave as impatient agents and borrow from the rest of the world. Despite this, the current account deficit leads to stationary dynamics. Second, we compare alternative monetary policy regimes (floating versus pegged) under productivity, government expenditure and global liquidity shocks and for alternative degrees of financial globalization. Our findings show that the impossible trinity is reversed in this model: higher degree of financial liberalization exacerbate the destabilizing effect of exchange rate fluctuations on foreign debt, consumption and output, hence it calls for more aggressive exchange rate targeting. Third, we analyze the trade-offs faced by the policy maker in this environment and derive the optimal (Ramsey) plan. The design of optimal policy is conducted in two steps. First, we lay down analytically the conditions that characterize the constrained pareto optimal allocation for the model economy under flexible prices; this allows us to highlight the role of real wedges in our economy. Second, we analyze the quantitative properties of the Ramsey plan for the economy with sticky prices. We find that monetary policy should deviate from price stability and smooth exchange rate fluctuations, the more so the higher the degree of financial liberalization. The Ramsey planner faces a trade off 
between stabilizing domestic prices, both in the durable and the non-durable sector, as this serves the goal of closing the price adjustment costs, and stabilizing fluctuations in the exchange rate. Movements in the latter, indeed, tend to amplify the fluctuations of the wedges, induced by the presence of the collateral constraint, on both, the marginal rate of substitution between durable and non-durable consumption and the marginal rate of substitution between non-durable consumption at two different dates. Through those channel, indeed, financial globalization can amplify inefficient fluctuations in consumption. The first of those two goals is achieved by targeting solely domestic inflation, while the second requires exchange rate targeting. The second motive tends to prevail, the more so in presence of increasing financial openness.

The rest of the paper proceeds as follows. Section 2 presents the model. Section 3 demonstrates how to obtain a stationary equilibrium. Section 4 describes the transmission mechanism in this model. Section 5 shows the comparison of alternative monetary policy regimes under alternative degree of financial liberalization. Section 6 shows the results of the optimal policy plan. Section 7 concludes.

\section{Related Literature}

Our paper contains both positive and normative results and because of this it is related to several strands of the literature.

In the open economy literature borrowing limits have been used to analyse various issues such as sudden stops (see Mendoza [61], Chari et al. [22]), over-borrowing (see Uribe [84], Benigno et al. [14]), global imbalances (see Mendoza et al. [63]), macroeconomic volatility (see Perri and Quadrini [69]) and welfare gains from financial integration (see Mendoza et al. [62], Aoki et al. [2]). All those studies analyze borrowing constraints in RBC economies and do not analyze optimal monetary policy. Additionally all those studies focus on borrowing constraints, in which physical capital or other forms of pleadable income play the role of collateral. An exception is given by Iacoviello and Minetti[42], who introduce in an RBC model a constraint with housing collateral to explain output co-movements across countries. This paper, on the contrary, considers the role of durable goods as collateral. The reason for the latter modeling assumption comes from the fact that there is significant evidence that consumers' loans require the borrower to post some collateral 
and that housing or durable goods represent, in most economies, the largest form of collateral (see Black et al. [17] and Attanasio et al. [4]).

In the open economy literature other papers have studied the effects of financial globalization (see Broner and Ventura [18], Devereux and Sutherland [32]) and its link with monetary policy (Devereux and Sutherland [32]). Most papers have modelled financial globalization in the form of international portfolio asset allocation, while we focus on collateral constrained lending.

The stabilization properties of alternative exchange rate regimes have been studied in several other papers, which introduce financial frictions in open economy models. For instance, See Cespedes, Chang and Velasco [21], Gertler, Gilchrist and Natalucci [40], Faia [34] introduce a financial accelerator mechanism in open economy and show that fixed exchange rates can be more destabilizing than floating exchange rates. Lahiri, Singh and Vegh [52] challenge the standard Mundell-Fleming prescription by showing that in presence of segmented asset markets floating exchange rate regimes perform better than fixed exchange rates, when shocks are real, and viceversa, when shocks originate in the money market. Our paper shows that the introducing financial frictions in the form of collateral constraints consistently leads to a superiority of pegging the exchange rates, the reason being that fluctuations in the exchange rate destabilize foreign lending and, consequently, current account and consumption demand.

Our paper also analyzes the design of optimal monetary policy and the scope for exchange rate targeting. In this respect our work is related to a strand of the open economy literature which studies optimal monetary policy. The classical analysis in Clarida, Gali and Gertler [25] and Gali and Monacelli [38] concludes that optimal monetary in a open economy models should target solely producer price inflation. The rationale for such an inward looking strategy comes from proving the isomorphism between the competitive equilibrium relations characterizing the closed and the open economy models. In this context the scope for exchange rate stabilization is absent. The limited role for exchange rate targeting is confirmed in Devereux and Engel [31], who, by reviving a popular argument due to Friedman [36], assert that in the presence of price stickiness, exchange rate movements should be instrumental to have the economy replicate the allocation under purely flexible prices, which implies maintaining constant mark-ups. A motive for deviating from strict markup stabilization generally lies in the possibility of strategically affecting the terms of trade (the relative 
price of imports). A terms of trade variation, by altering domestic residents' purchasing power, affects consumption for any given level of output (labor effort). Previous contributions, Corsetti and Pesenti [27], Sutherland [82], Benigno and Benigno [12], have shown that this terms-of-trade motive vanishes if either of two conditions holds: (i) the intratemporal elasticity of substitution between domestic and imported goods is unitary; (ii) that same elasticity coincides with the intertemporal elasticity of substitution in consumption. More recently Faia and Monacelli [35] have shown that in a small open economy with home bias the policy maker will optimally deviate from an inward looking strategy and will target the exchange rate. Under home bias, variations in the terms of trade induce also variations in the real exchange rate, which, in turn, affect domestic consumption via international risk-sharing (for any given level of foreign consumption). In the present paper, we show that in an economy with incomplete international markets and collateral constraints on external debt, there is an additional and independent motive for exchange rate targeting, namely the need for stabilizing fluctuations in external debt. Later indeed we show that exchange rate movements exacerbate the fluctuations on the wedges induced by the collateral constraint.

\section{A Small Open Economy with Collateral Constraints}

There is a small open economy (which we refer to as the domestic economy) and the rest of the world. A crucial assumption in our set-up is that residents of the small open economy have lower discount factors compared to agents populating the rest of the world. As domestic agents are impatient, in equilibrium the small open economy will have a negative asset position; we will return on this point later.

The small open economy is populated by infinitely lived agents who consume non-durable and durable goods, work, invest in domestic government claims and require loans to finance expenditures. Consumption in durable and non-durable goods is financed through foreign lending, which takes the form of non-state contingent securities and is bounded above by a fraction of the future value of the collateral - i.e. durable goods. Because of this, the net asset position, both in the long and in the short run, is linked to the future value of collateral. Demand for durable goods is justified since they enter the utility function. The assumption of a financially constrained open economy is justified by the inability of foreign lenders to implement perfect monitoring. Under those circum- 
stances the tightness of the borrowing limit depends on the degree of information asymmetry, of financial market integration and of debt repossession ability which in turn depends upon legal and institutional arrangements. There are two production sectors in this economy: the durable good sector and the non-durable goods sector. Firms in both sectors are monopolistic competitive and face Rotemberg [75] adjustment costs.

\subsection{Domestic Households}

Let $s^{t}=\left\{s_{0}, \ldots . s_{t}\right\}$ denote the history of events up to date $t$, where $s_{t}$ denotes the event realization at date $t$. The date 0 probability of observing history $s^{t}$ is given by $\rho_{t}$. The initial state $s^{0}$ is given so that $\rho\left(s^{0}\right)=1$. Henceforth, and for the sake of simplifying the notation, let's define the operator $E_{t}\{\cdot\} \equiv \sum_{s_{t+1}} \rho\left(s^{t+1} \mid s^{t}\right)$ as the mathematical expectations over all possible states of nature conditional on history $s^{t}$.

Agents maximize the following expected discounted sum of utilities:

$$
E_{t}\left\{\sum_{t=0}^{\infty} \beta^{t} U\left(C_{I, t}, N_{t}\right)\right\}
$$

where total labour hours are denoted with $N_{t}$, total aggregate consumption is denoted by:

$$
C_{I, t}=\left((1-\gamma)^{\frac{1}{\theta}} C_{t}^{\frac{\theta-1}{\theta}}+\gamma^{\frac{1}{\theta}} \tilde{D}_{t}^{\frac{\theta-1}{\theta}}\right)^{\frac{\theta}{\theta-1}}
$$

where $P_{I, t} \equiv\left[(1-\gamma) P_{t}^{1-\eta}+\gamma P_{d, t}^{1-\eta}\right]^{\frac{1}{1-\eta}}, P_{t}$ is the aggregate price index for non-durable consumption and $P_{d, t}$ is the aggregate price index for durable consumption. Non-durable consumption is given by a Dixit-Stiglitz consumption aggregator of domestic and imported goods (with $\eta$ being the intratemporal elasticity):

$$
C_{t}=\left(\alpha^{\frac{1}{\eta}} C_{h, t}^{\frac{\eta-1}{\eta}}+(1-\alpha)^{\frac{1}{\eta}} C_{f, t}^{\frac{\eta-1}{\eta}}\right)^{\frac{\eta}{\eta-1}}
$$

and durable consumption given by:

$$
\tilde{D}_{t}=D_{t-1}-\frac{\psi}{2} \frac{\left(X_{t}-\delta D_{t-1}\right)^{2}}{D_{t-1}}
$$

where $D_{t-1}$ is the real value of the stock of durable goods which is held in positive amount for it generates utility, $X_{t}=D_{t}-(1-\delta) D_{t-1}$ is investment in durable goods, $\delta$ is the depreciation rate 
and the function $\frac{\psi}{2}\left(\frac{X_{t}-\delta D_{t-1}}{D_{t-1}}\right)^{2}$ represents an adjustment cost function. Preferences are concave, bounded above and satisfy Inada conditions and $\beta$ represents the discount factor of domestic agents. As domestic residents are impatient we assume that $\beta<\mu$, with $\mu$ being the discount factor of foreign residents.

Afert defining $P_{t} \equiv\left[\alpha P_{h, t}^{1-\eta}+(1-\alpha) P_{f, t}^{1-\eta}\right]^{\frac{1}{1-\eta}}$ as the domestic price index and $S_{t}=\frac{P_{f, t}}{P_{h, t}}$ as the terms of trade, optimal demands for domestic and imported goods imply the following relation:

$$
\frac{C_{h, t}}{C_{f, t}}=\frac{\alpha}{(1-\alpha)}\left(S_{t}\right)^{\eta}
$$

The household receives at the beginning of time $t$ a labor income of $W_{t} N_{t}$, where $W_{t}$ is the nominal wage. Agents can invest in domestic (nominal) government claims, $B_{t}$, which pay a gross nominal interest rate one period later. Furthermore, they can borrow in foreign currency, $B_{t}^{*}$. The gross nominal interest rate to be paid on foreign borrowing is given by $R_{t}^{* n}$. Agents can also buy and sell durables, $D_{t}$, in an internal competitive market ${ }^{5}$. Agents are also owners of the monopolistic sectors which produce durable and non-durable goods, hence they receive profits $\Pi_{d, t}$ and $\Pi_{h, t}$. The price of durable in terms of consumption goods is denoted $Z_{t}=\frac{P_{d, t}}{P_{t}}$. Finally, agents pay lump sum transfers, $\tau_{t}$.

The sequence of budget constraints in nominal terms reads as follows:

$$
P_{t} C_{t}-R_{t-1}^{n} B_{t-1}+e_{t} R_{t-1}^{n, *} B_{t-1}^{*}+P_{t} Z_{t}\left(D_{t}-D_{t-1}(1-\delta)\right) \leq W_{t} N_{t}-B_{t}+e_{t} B_{t}^{*}+\tau_{t}+\Pi_{h, t}+\Pi_{d, t}
$$

where $e_{t}$ is the nominal exchange rate. It is now convenient to re-state the budget constraint in real terms:

$$
C_{t}-R_{t-1}^{n} \frac{b_{t-1}}{\pi_{t}}+R_{t-1}^{n, *} \frac{e_{t}}{e_{t-1}} \frac{b_{t-1}^{*}}{\pi_{t}}+Z_{t}\left(D_{t}-D_{t-1}(1-\delta)\right)=\frac{W_{t}}{P_{t}} N_{t}-b_{t}+b_{t}^{*}+\frac{\tau_{t}}{P_{t}}+\frac{\Pi_{h, t}}{P_{t}}+\frac{\Pi_{d, t}}{P_{t}}
$$

where $e_{t} \frac{B_{t}^{*}}{P_{t}}=b_{t}^{*}$ are real international bonds and $\frac{B_{t}}{P_{t}}=b_{t}$ are real domestic bonds. The crucial assumption in this model is that agents face borrowing constraints on the world market. As the foreign lenders are not able to fully repossess their funding, debt and its services are guaranteed as repayable up to a certain fraction of the collateral value (limited liability constraint). The

\footnotetext{
${ }^{5}$ As the bigger fraction of durables is represented by residential housing, non-tradability is an empirically plausible assumption.
} 
collateral corresponds to the future value of the durable good $P_{t+1} Z_{t+1} D_{t}$. To formalize this idea let's assume that domestic households face the following period-by-period borrowing constraint on foreign nominal debt:

$$
R_{t}^{* n} B_{t}^{*} \leq \Omega E_{t}\left\{\frac{P_{t+1}}{e_{t+1}} Z_{t+1} D_{t}\right\}
$$

which states that the debt repayment service in foreign currency (the currency of the lender), needs to be less or equal to the expected foreign-currency value of the collateral. Constraint 8 can arise in presence of limited enforcement without default ${ }^{6}$. In equilibrium debt repudiation never occurs as the lender would repossess the whole collateral value. Collateral is in fact used as a promise for repayment. The parameter $\Omega$ is the fraction of the future value of the collateral that is guaranteed to be repaid and can be interpreted as a down payment. Hence $\Omega$ reflects the degree of information asymmetry, of financial market integration and of debt repossession ability of foreign lenders which in turn depends upon legal and institutional arrangements. In general it is assumed that it is costly for foreign lenders to repossess the entire collateral value. Since increasing $\Omega$ allows to relax the borrowing limit and to increase the availability of foreign lending, we assume that higher degree of financial liberalization is associated with higher value of $\Omega$.

Once again it is convenient to re-state the constraint in real terms:

$$
R_{t}^{n, *} b_{t}^{*} \leq \Omega E_{t}\left\{\frac{\pi_{t+1} Z_{t+1} D_{t}}{\frac{e_{t+1}}{e_{t}}}\right\}
$$

where $e_{t} \frac{B_{t}^{*}}{P_{t}}=b_{t}^{*}$ are real international bonds. From equation 9 it is clear that fluctuations in the real exchange rate influence the link between collateral and net asset accumulation: a real exchange rate depreciation can increase the value of collateral and ease the borrowing constraint. Let's assume that assume a separable utility. Households choose the set of processes $\left\{C_{t}, N_{t}, b_{t}, b_{t}^{*}, D_{t}\right\}_{t=0}^{\infty}$ taking as given the set of processes $\left\{P_{t}, W_{t}, R_{t}^{n}, R_{t}^{n *}, Z_{t}\right\}_{t=0}^{\infty}$ and the initial wealth $b_{0}, b_{0}^{*}, D_{0}$ so as to maximize 1 subject to 7 and 9 . Let's define $U_{c, t} \xi_{t}$ as the lagrange multiplier on 9 . The following optimality conditions must hold:

$$
U_{c, t} \frac{W_{t}}{P_{t}}=-U_{n, t}
$$

\footnotetext{
${ }^{6}$ Perri [70] in the New Palgrave Dictionary of Economics clarifies that default occurs in equilibrium when limited enforcement is coupled with other frictions.
} 


$$
\begin{gathered}
U_{c, t}=\beta E_{t}\left\{\frac{R_{t}^{n}}{\pi_{t+1}} U_{c, t+1}\right\} \\
U_{c, t}-R_{t}^{n *} \xi_{t} U_{c, t}=\beta E_{t}\left\{U_{c, t+1} \frac{e_{t+1}}{e_{t}} \frac{R_{t}^{n *}}{\pi_{t+1}}\right\} \\
Z_{t} U_{c, t}-\Omega U_{c, t} \xi_{t} E_{t}\left\{\frac{\pi_{t+1} Z_{t+1}}{\frac{e_{t+1}}{e_{t}}}\right\}+U_{\tilde{D}_{t}} \psi\left(\frac{D_{t}-D_{t-1}}{D_{t-1}}\right) \\
=E_{t}\left\{\beta U_{D_{t+1}}\left(1+\psi\left(\frac{D_{t+1}-D_{t}}{D_{t}}\right)+\frac{\psi}{2} \frac{\left(D_{t+1}-D_{t}\right)^{2}}{D_{t}^{2}}\right)\right\}+(1-\delta) \beta E_{t}\left\{Z_{t+1} U_{c, t+1}\right\}
\end{gathered}
$$

Equation 10 gives the optimal choice of labor supply. Note that in this context the borrowing constraint does not affect directly the marginal rate of substitution between consumption and leisure. Equation 11 is the first order condition on domestic bond holding. Equation 12 is the first order condition with respect to foreign bonds and it can be interpreted as a modified Euler condition; a binding borrowing constraint (which implies a positive $\xi_{t}$ ) induces a intratemporal distortion in the value of consumption between two different dates

Equation 13 is the efficiency condition for the intertemporal choice of the durable good. The intuition for this equation is as follows. The time $t$ marginal cost of foregoing one unit of nondurable consumption (weighted by the price of the durable) is equated to its marginal gain which has three components. The first is the direct marginal utility of one additional unit of durable investment now and in the future:

$$
E_{t}\left\{\beta \Delta_{D_{t+1}}^{\sim}\left(1+\psi\left(\frac{D_{t+1}-D_{t}}{D_{t}}\right)+\frac{\psi}{2} \frac{\left(D_{t+1}-D_{t}\right)^{2}}{D_{t}^{2}}\right\}\right.
$$

The second is the expected marginal utility of one unit of non-durable consumption postponed into the future:

$$
\beta(1-\delta) E_{t}\left\{Z_{t+1} U_{c, t+1}\right\}
$$

If the agent shifts today one unit of consumption from non-durable to durable goods, by acquiring more collateral, he can increase his debt availability which in turn raises future consumption demand for non-durables.

The third component of the marginal gain is given by the shadow value of relaxing the liability constraint, $\Omega U_{c, t} \xi_{t} E_{t}\left\{\frac{\pi_{t+1} Z_{t+1}}{\frac{e_{t+1}}{e_{t}}}\right\}$, as an additional unit of collateral becomes available. From equation 13 it stands clear that a binding borrowing constraint induces an intertemporal distortion of 
magnitude $\Omega U_{c, t} \xi_{t} E_{t}\left\{\frac{\pi_{t+1} Z_{t+1}}{\frac{e_{t+1}}{e_{t}}}\right\}$ in the value of durable consumption between two different dates. Such wedge behaves as a tax on durable goods and changes in its magnitude can shift consumption from durable to non-durable goods. An increase in the parameter $\Omega$ has both a direct and an indirect impact on this wedge. Those two effects move actually in opposite directions. The direct impact comes form the fact that the size of the wedge itself depends upon $\Omega$. A higher value of this parameter increases credit availability therefore acting as a positive wealth shock that reduces the demand for collateralizable durable goods. In other words an increase in $\Omega$ increases the tax on durable good, as it reduces the marginal benefit of durable relative to non-durable at the current date. The indirect impact comes from the fact a higher value of $\Omega$, by relaxing the borrowing limit, reduces the size of $\xi_{t}$. As the shadow value of the borrowing limit decreases, the marginal benefit of one additional unit of collateral today increases. As $\xi_{t}$ enters the durable tax component, a decrease in $\xi_{t}$ will induce agents to substitute non-durable with durable consumption goods. Later on, our quantitative simulations will show that the first effect tends to prevail so that, in response to shocks, we observe an increase in the volatility of non-durable consumption and a decrease in the volatility of durable consumption.

\subsection{Foreign Households}

The rest of the world can be thought as approximating a continuum of countries whose trade balance is zero. This implies that $P_{f, t}^{*}=P_{t}^{*}$. Agents in the rest of the world behave as standard consumption smoother. Let's define $\mu$ as the discount factor of foreign residents. This implies that the following consumption Euler condition holds:

$$
U_{c^{*}, t}=\mu E_{t}\left\{\frac{R_{t}^{* n}}{\pi_{t+1}^{*}} U_{c^{*}, t+1}\right\}
$$

Nominal interest rate in the rest of the world are exogenously given; they can become timevarying when modeled as random shocks. Furthermore foreign households face the following optimal demand for domestic goods:

$$
C_{h, t}^{*}=\alpha^{*} Y_{t}^{*}\left(\frac{P_{h, t}^{*}}{P_{t}^{*}}\right)^{-\eta}
$$




\subsection{Open Economy Relations}

It is assumed that the law of one pice holds continuously so that $P_{h, t}=e_{t} P_{h, t}^{*}$ and $P_{f, t}=e_{t} P_{f, t}^{*}$ where $e_{t}$ is the nominal exchange rate. Given the definition for the terms of trade and the CPI index, the following equation for the CPI inflation (for non-durable goods) holds:

$$
\pi_{t}=\pi_{h, t} \frac{\left(\alpha+(1-\alpha) S_{t}^{1-\eta}\right)^{\frac{1}{1-\eta}}}{\left(\alpha+(1-\alpha) S_{t-1}^{1-\eta}\right)^{\frac{1}{1-\eta}}}
$$

The real exchange rate is given by:

$$
q_{t}=\left[\alpha\left(S_{t}\right)^{\eta-1}+(1-\alpha)\right]^{\frac{1}{1-\eta}}=g\left(S_{t}\right)
$$

\subsection{Non-durable Goods Production Sector}

Firms in the non-durable production sector are monopolistic competitive and face Rotemberg [75] adjustment costs. They produce different varieties of goods according to the following production function:

$$
Y_{t}(i)=A_{h, t} N_{h, t}(i)
$$

As non-durable goods are aggregated according to the following Dixit-Stiglitz aggregators $C_{h, t} \equiv$ $\int_{0}^{1}\left[C_{h, t}(i)^{\frac{\varepsilon-1}{\varepsilon}} d i\right]^{\frac{\varepsilon}{\varepsilon-1}}$ and $C_{f, t} \equiv \int_{0}^{1}\left[C_{f, t}(i)^{\frac{\varepsilon-1}{\varepsilon}} d i\right]^{\frac{\varepsilon}{\varepsilon-1}}$ firms face the following demand function:

$$
Y_{t}(i)=\left(\frac{P_{h, t}(i)}{P_{h, t}}\right)^{-\varepsilon} Y_{t}
$$

Firms choose the path of prices $P_{h, t}(i)$ to maximize expected discounted future profits:

$$
E_{0}\left\{\sum_{t=0}^{\infty} \Lambda_{0, t}\left(Y_{t}(i) P_{h, t}(i)-W_{t} N_{h, t}(i)-\frac{\omega}{2}\left(\frac{P_{h, t}(i)}{P_{h, t-1}(i)}-1\right)^{2} P_{h, t}\right)\right\}
$$

subject to the demand constraint in 20 , with $\Lambda_{t, t+1} \equiv \frac{\Lambda_{0, t+1}}{\Lambda_{0, t}} \equiv \beta E_{t}\left\{\frac{1}{1-\psi_{t}} \frac{\lambda_{t+1}}{\lambda_{t}} \frac{P_{t}}{P_{t+1}}\right\}$ being the borrower's stochastic discount factor and with $\frac{\omega}{2}\left(\frac{P_{h, t}(i)}{P_{h, t-1}(i)}-1\right)^{2} P_{h, t}$ representing firm's costs of adjusting prices. The parameter $\omega$ represents slugginesh in price adjustment. Let's define $m c_{h, t}$ as 
the lagrange multiplier on constraint 20. After imposing symmetry and substituting for the labour market equilibrium conditions, we obtain the following optimality condition for prices:

$$
\begin{aligned}
\omega\left(\pi_{h, t}-1\right) \pi_{h, t}= & A_{h, t} N_{h, t} \varepsilon\left[\frac{(1-\varepsilon)}{\varepsilon}+\frac{1}{A_{h, t}} \frac{-U_{N, t}}{U_{T, t}}\left[\alpha+(1-\alpha) S_{t}^{1-\eta}\right]^{\frac{1}{1-\eta}}\right] \\
& +\omega \beta E_{t}\left\{\left(\frac{1}{1-\psi_{t}}\right) \frac{U_{c, t+1}}{U_{c, t}}\left[\frac{\alpha+(1-\alpha) S_{t}^{1-\eta}}{\alpha+(1-\alpha) S_{t+1}^{1-\eta}}\right]^{\frac{1}{1-\eta}}\left(\pi_{h, t+1}-1\right) \pi_{h, t+1}\right\}
\end{aligned}
$$

\subsection{Durable Goods Production Sector}

Firms in the durable goods production sector solve a similar maximization problem than firms in the non-durable sector. Hence optimal pricing condition reads as follows:

$$
\begin{aligned}
\omega_{d}\left(\pi_{d, t}-1\right) \pi_{d, t}= & A_{d, t} N_{d, t} \varepsilon\left[\frac{(1-\varepsilon)}{\varepsilon}+\frac{1}{Z_{t}} \frac{-U_{N, t}}{U_{c, t} A_{d, t}}\right] \\
& +\omega_{d} \beta E_{t}\left\{\left(\frac{1}{1-\psi_{t}}\right) \frac{U_{c, t+1}}{U_{c, t}} \frac{Z_{t+1}}{Z_{t}}\left(\pi_{d, t+1}-1\right) \pi_{d, t+1}\right\}
\end{aligned}
$$

\subsection{Government Budget Constraint}

There is a passive fiscal authority who issues bonds to cover the budget deficit. Hence the government budget constraint reads as follows:

$$
B_{t}-R_{t-1}^{n} B_{t-1}=g_{t}-\tau_{t}
$$

\subsection{Market Clearing}

Given that labor is immobile across countries, labor market clearing implies:

$$
N_{d, t}+N_{h, t}=N_{t}
$$

For good markets to be cleared in country $h$, total purchases of durable goods must equalize total domestic production:

$$
A_{d, t} N_{d, t}=D_{t}-(1-\delta) D_{t-1}+\frac{\omega_{d}}{2}\left(\pi_{d, t}-1\right)^{2}
$$

As non-durables are traded market clearing requires that total production is equalized to domestic and foreign demand: 


$$
A_{h, t} N_{h, t}=\alpha Y_{t}\left(\frac{P_{h, t}}{P_{t}}\right)^{-\eta}+(1-\alpha) Y_{t}^{*}\left(\frac{P_{h, t}^{*}}{P_{t}^{*}}\right)^{-\eta}+\frac{\omega}{2}\left(\pi_{h, t}-1\right)^{2}+g_{t}
$$

where $g_{t}$ represents exogenous government spending and follows a $\operatorname{AR}(1)$ shock.

\subsection{UIP and Asset Evolution}

The arbitrage condition between domestic government claims and foreign bond holdings, equations 11 and 12, implies the following uncovered interest rate parity:

$$
R_{t}^{n}=R_{t}^{* n} \frac{\left[\xi_{t}+\beta E_{t}\left\{\frac{e_{t+1}}{e_{t}} \frac{U_{c, t+1}}{\pi_{t+1} U_{c, t}}\right\}\right]}{\left[\beta E_{t}\left\{\frac{U_{c, t+1}}{\pi_{t+1} U_{c, t}}\right\}\right]}
$$

The evolution of foreign debt is obtained by the aggregate budget constraint of the domestic residents:

$$
C_{t}+Z_{t}\left(D_{t}-D_{t-1}(1-\delta)\right)+\frac{W_{t} N_{t}}{P_{t}}+\frac{\Pi_{h, t}}{P_{t}}+\frac{\Pi_{d, t}}{P_{t}}-R_{t-1}^{n} \frac{b_{t-1}}{\pi_{t}}+b_{t}-\frac{\tau_{t}}{P_{t}}=b_{t}^{*}-R_{t-1}^{n *} \frac{e_{t}}{e_{t-1}} \frac{b_{t-1}^{*}}{\pi_{t}}
$$

Substituting the expression for the profit functions, $\frac{\Pi_{h, t}}{P_{t}}+\frac{\Pi_{d, t}}{P_{t}}$, and imposing the government budget constraint, deliver:

$$
A_{h, t} N_{h, t}-\Psi \frac{\omega}{2}\left(\pi_{h, t}-1\right)^{2}-g_{t}+Z_{t}\left(A_{d, t} N_{d, t}-\frac{\omega_{n}}{2}\left(\pi_{d, t}-1\right)^{2}\right)+\frac{U_{n, t}}{U_{c, t}} N_{t}=b_{t}^{*}-R_{t-1}^{n *} \frac{e_{t}}{e_{t-1}} \frac{b_{t-1}^{*}}{\pi_{t}}
$$

Equations 9 and 29 together clarify the link between durable prices and net asset accumulation. The level of net asset accumulation depends on the value of collateral as from equation 9, while its accumulation is linked to current account deficits by equation 29. Notice that the dependence of net asset accumulation on the stock of durable, which is a state variable, amplifies the persistence of fluctuations in the current account.

By merging the market clearing conditions, equations 25 and 26, with the expression for net asset accumulation, equation 29, one obtains a relation linking the net asset accumulation to the determinants of net exports (derivations are shown in Appendix 1):

$$
b_{t}^{*}-R_{t-1}^{n *} \frac{e_{t}}{e_{t-1}} \frac{b_{t-1}^{*}}{\pi_{t}}=(1-\alpha) C_{t}^{*} \frac{S_{t}^{\eta}}{\left[\left(\alpha+(1-\alpha) S_{t}^{1-\eta}\right)\right]^{\frac{1}{1-\eta}}}-C_{t}(1-\alpha) \frac{S_{t}^{1-\eta}}{\left(\alpha+(1-\alpha) S_{t}^{1-\eta}\right)}
$$


The term $(1-\alpha) C_{t}^{*} \frac{S_{t}^{\eta}}{\left[\left(\alpha+(1-\alpha) S_{t}^{1-\eta}\right)\right]^{\frac{1}{1-\eta}}}$ represents the exports toward the rest of the world, while the term $C_{t}(1-\alpha) \frac{S_{t}^{1-\eta}}{\left(\alpha+(1-\alpha) S_{t}^{1-\eta}\right)}$ represents imports. The above relation states that in equilibrium the net asset accumulation must equate net exports.

\section{Uniqueness and Stationarity of Long Run Asset Position}

Proposition 1. Under the following assumptions:1. The Hessian of the utility function is semidefinite negative and Inada conditions for consumption hold. 2. the discount factor of domestic agents is lower than that of foreign households, $\beta, \mu \in(0,1)$ and $\beta<\mu^{7}$.3. The production function, $F(N)$, is homogeneous of degree 1 with $F \in C^{2}, F_{N}>0, F_{N N} \leq 0$. Moreover $F(0)=0$, $\lim _{N \rightarrow 0} F^{\prime}(N)=+\infty, \lim _{N \rightarrow \infty} F^{\prime}(N)=0$. In a close neighborhood of the steady state, the collateral constraint:

$$
R_{t}^{n, *} b_{t}^{*} \leq \Omega E_{t}\left\{\frac{\pi_{t+1} Z_{t+1} D_{t}}{\frac{e_{t+1}}{e_{t}}}\right\}
$$

is binding at any date and any state and determines uniquely the net asset position.

Proof. Following Becker [9] and Becker and Foias [10], [11] we can show that the constraint 31 binds if there exist a dominant consumer, namely a patient household willing to lend. Consider the Euler condition of domestic residents with respect to foreign lending:

$$
1-R_{t}^{n *} \xi_{t}=\beta E_{t}\left\{\frac{U_{c, t+1}}{U_{c, t}} \frac{e_{t+1}}{e_{t}} \frac{R_{t}^{n *}}{\pi_{t+1}}\right\}
$$

By evaluating equation 32 at the steady state and substituting the steady-state relation $R^{n *}=$ $\frac{1}{\mu}$ (which is obtained by the steady state version of equation 16), we obtain:

$$
\mu-\beta=\xi>0
$$

As the lagrange multiplier is positive, the constraint is binding at the steady state. Hence the net asset position of the small open economy is uniquely determined by the borrowing constraint.

Corollary. The net asset position does not posses unit roots.

\footnotetext{
${ }^{7}$ This assumption is equivalent to assume that in steady state $\beta R \leq 1$. As it is known in the savings literature (see Aiyagari [1]), utility functions with positive third derivatives generate precautionary savings. Additionally precautionary saving motives arise in presence of liquidity constraints, see Zeldes [86], Jappelli and Pagano [43], Deaton [30]. Precautionary saving is sustainable only with a steady state in which $\beta R \leq 1$. Iacoviello [41] shows that such an assumption coupled with the assumption of small shocks guarantees that in equilibrium the constraint binds.
} 
As the Euler condition in the steady state, 33, does not depend on initial conditions but solely on model parameters, the net asset position does not posses unit roots.

The above results move a step forward in understanding the conditions for stationarity of the current account. In a seminal work, Obstfeld and Rogoff [66] have shown that under market incompleteness the steady state of an open economy model is characterized by unit roots. This implies that the steady state depends on initial values and transient shocks have long run effects. In previous works several methods have been proposed to recover stationarity: parameter and functional form restrictions (see Cole and Obstfeld [26], Corsetti and Pesenti [27]), endogenous discount factor (Uzawa-type preferences), debt-elastic interest-rate premium, convex portfolio adjustment costs (see Schmitt-Grohe and Uribe [78]) or the assumption of finitely lived agents (see Ghironi [39]). Notice that imposing collateral constraints is iso-morphic to the introduction of debt elastic interest rates, as the wedge, induced by the collateral constraint on the marginal rate of substitution between consumption at two different dates, behaves as a risk premium. However, while debt elastic interest rates require an exogenously imposed long run level of external assets, collateral constraints require fixing the debt to asset ratios, a value which can be more easily calibrated from the data.

\section{The Transmission of Shocks}

Before turning to the evaluation of different exchange rate regimes and to the optimal policy design, it is instructive to characterize the transmission mechanism in our model under floating exchange rates. We do that by looking at impulse response analysis under two shocks: productivity and global liquidity shocks. We have chosen to consider a productivity shock as this is the main source of business cycle fluctuations. We have chosen to consider a global liquidity shock as empirical evidence has shown that this shock has had a significant role in explaining house price movements and in accounting for global imbalances ${ }^{8}$. Furthermore in a model with sticky prices, an interest rate shock plays also the role of a demand shock.

\footnotetext{
${ }^{8}$ See for instance Sousa and Zaghini 2006, Räffer and Stracca 2006, Belke, Orth and Setzer 2008.
} 


\subsection{Calibration}

In this section we analyze the response of the economy to shocks with the goal of comparing alternative monetary policy regimes under different degrees of financial globalization. Calibration is set as follows.

Preferences. Time is measured in quarters. We assume that $\beta<\mu, \beta=0.98$ (see Krusell and Smith [51]) and $\mu=0.99$. The structure of the model implies that the real interest rate of the rest of the world is pinned down by the patient consumers, hence it is equal to $\frac{1}{\mu}$. Utility is separable in aggregate consumption, $C_{I, t}$ and labour, $N_{t}$, and takes the following form: $\frac{C_{I, t}^{1-\sigma}}{1-\sigma}-v \frac{N_{t}^{1+\tau}}{1+\tau}$. The parameter $\sigma$ is set equal to 1 as in most of the RBC literature. The parameter $\tau$ is set equal to 1 and the parameter $v$ is chosen so as to generate a steady state employment of 0.3 in the non-durable sector.

Production. The elasticity of substitution for different varieties, $\varepsilon$, is set to 8 . This implies a mark-up of about 15 percent. In order to parameterize the degree of price stickiness $\omega$, we observe that, by log-linearizing equation 21 we can obtain an elasticity of inflation to real marginal cost (normalized by the steady-state level of output) ${ }^{9}$ that takes the form $\frac{\varepsilon-1}{\omega}$. This allows a direct comparison with empirical studies on the New Keynesian Phillips curve such as Galí and Gertler [37] and Sbordone [73] using a Calvo-Yun approach. In those studies, the slope coefficient of the log-linear Phillips curve can be expressed as $\frac{(1-\widehat{\vartheta})(1-\beta \widehat{\vartheta})}{\widehat{\vartheta}}$, where $\widehat{\vartheta}$ is the probability of not resetting the price in any given period in the Calvo-Yun model. For any given values of $\varepsilon$, which entails a choice on the steady-state level of the markup, we can thus build a mapping between the frequency of price adjustment in the Calvo-Yun model $\frac{1}{1-\widehat{\vartheta}}$ and the degree of price stickiness $\vartheta$ in the Rotemberg setup. The recent New Keynesian literature has usually considered a frequency of price adjustment of four quarters as realistic. Recently, Bils and Klenow [16] have argued that the observed frequency of price adjustment in the U.S. is higher, and in the order of two quarters. As a benchmark, we parameterize $\frac{1}{1-\widehat{\vartheta}}=4$, which implies $\widehat{\vartheta}=0.75$. Given $\varepsilon=8$, the resulting stickiness parameter satisfies $\vartheta=\frac{Y \widehat{\vartheta}(\varepsilon-1)}{(1-\widehat{\vartheta})(1-\beta \widehat{\vartheta})} \approx 27$, where $Y$ is steady-state output.

The elasticity of substitution between home and foreign consumption, $\eta$, is set to 3 . Empirical

\footnotetext{
${ }^{9}$ To produce a slope coefficient directly comparable to the empirical literature on the New Keynesian Phillips curve this elasticity needs to be normalized by the level of output when the price adjustment cost factor is not explicitly proportional to output, as assumed here.
} 
studies assign values to this parameter that range from 2 to 5 . The share of home consumption goods in the domestic country, $\alpha$, is set to 0.7 , which implies, compatibly with empirical evidence for industrialized countries, a degree of openness of 0.3 .

Durables. The elasticity of substitution between durable and non-durable goods is set equal to 1 , while the share of durable spending is set to 0.2 , a value consistent with industrialized countries. Consistently with Erceg and Levin [33] the parameter $\psi$ in the adjustment cost function is set to 300. This value allows to obtain a volatility for durable goods higher than the one for non-durable, as suggested by empirical evidence. The quarterly depreciation rate of the durable stock is set to $\delta=0.39764$; this value is consistent with a specification of the durable investment which includes both consumer durables and residential investment. The baseline parameter that defines the tightness of the endogenous borrowing limit is set consistently with loan to value ratios for the industrialized countries over the period $1952-2005^{10}$ which is 0.25 . This parameter is varied in the simulations in order to assess the role of financial globalization.

Stochastic processes. Following Prescott [71] and McCallum and Nelson [57] the standard deviation of the productivity shock is set to 0.007 and its persistence is set to 0.95 . Log-government consumption evolves according to the following exogenous process, $\ln \left(\frac{g_{t}}{g}\right)=\rho_{g} \ln \left(\frac{g_{t-1}}{g}\right)+\varepsilon_{t}^{g}$, where the steady-state share of government consumption, $g$, is set so that $\frac{g}{y}=0.25$ and $\varepsilon_{t}^{g}$ is an i.i.d. shock with standard deviation $\sigma_{g}$. Empirical evidence in Perotti [68] suggests $\sigma_{g}=0.008$ and $\rho_{g}=0.9$. We also introduce a global liquidity shock and interpret it as a shock to the aggregate process of money supply in the rest of the world. As such we formalize it as an $\operatorname{AR}(1)$ shock to foreign interest rate with $\sigma_{r}=0.00623$ and $\rho_{r}=0.6$. Such calibration is consistent with estimates of the interest rate process conducted by Rudebusch [76] and [77].

Monetary Policy regimes. There is an active monetary policy. The monetary authority sets the short term nominal interest rate by reacting to endogenous variables as in the general class of the Taylor rules:

$$
R_{t}^{n}=\left(\frac{\pi_{h, t}}{\bar{\pi}_{h}}\right)^{\varpi_{\pi}}\left(\frac{e_{t}}{e_{t-1}}\right)^{\frac{\varpi^{e}}{1-\varpi_{e}}}
$$

where $R_{t}^{n}=R_{t} \frac{P_{t+1}}{P_{t}}, \varpi_{\pi}$ is the weight the monetary authority puts on the deviation of inflation from the target $\bar{\pi}, \varpi_{e}$ is the weight that the monetary authority puts on the deviation of the

\footnotetext{
${ }^{10}$ See IMF Report 2008.
} 
exchange rate between two subsequent periods. We assign a value of 2 to the parameter $\varpi_{\pi}$. We have chosen to target the change in the exchange rate, $\frac{e_{t}}{e_{t-1}}$, rather than the level, as this enlarges the determinacy region as shown by Benigno, Benigno and Ghironi [13]. A regime of pure floating exchange rate is identified by the case $\varpi^{e}=0$. Pegged exchange rate regimes are identified by a Taylor rule of the form 34 in which $\varpi^{e}>0$. This parameter will be varied in the simulations from a low value of 0 to a high value of $0.9^{11}$.

\subsection{Dynamic Responses to Shocks}

Figure 1 shows the dynamic response of selected variables to a $1 \%$ productivity shock in the domestic economy. As it is standard in sticky prices models, output increases while inflation decreases. As technology has improved and since prices are sticky, firms save on labour demand, hence employment falls. The increase in output brings about an increase in non-durable and durable consumption demand. The response of durables shows an hump-shaped dynamic due to the presence of adjustment costs. The increase in durables is accompanied by a fall in its price. Overall, however, the future value of durables (the value of collateral) increases. The increase in the value of collateral allows to relax the borrowing constraint and to increase the supply of foreign debt, as it is shown by the fact that the lagrange multiplier deviates from zero. As consumption demand is higher than output, domestic residents increase their demand for foreign debt. In equilibrium foreign lending increases. The ensuing current account deficit induces a real exchange rate depreciation. Notice that such movements of the current account are consistent with a coutercyclical net exports dynamic, a fact well established in international data. Importantly the current account deficit (which is the counterpart of the foreign debt accumulation) shows a persistent dynamic. This is the sense in which our model can generate persistent global imbalances, despite the long run stationarity featured by the current account dynamic.

Figure 2 shows impulse response of selected variables to $1 \%$ global liquidity shocks. Several empirical studies have shown a link between housing demand (or durable demand) and the increase in global liquidity. We therefore analyze the property of an increase in global liquidity, interpreted a fall in foreign interest rate. The availability of foreign lending increases in this case. This

\footnotetext{
${ }^{11}$ It is not possible to quantify this parameter empirically since the classification between floating and pegged exchange rate regimes is only done at a qualitative level. For this reason its value is varied in the experiments.
} 
relaxes the borrowing constraint, therefore increasing the demand for both, durable and non-durable consumption. Such an increase is accompanied by an increase in domestic prices, $P_{h, t}$, which renders domestic goods less attractive. The ensuing switching expenditure effect implies a fall in foreign prices, $P_{f, t}$, and an exchange rate appreciation. Overall the CPI price index falls, as exports fall by more than the increase in domestic demand. The fall in aggregate demand induces a fall in employment and output. Hence while beneficial on consumption demand such an ease in global liquidity has a detrimental effect on output.

\section{Exchange Rate Regimes and Financial Globalization}

We now turn to the evaluation of the stabilization properties of exchange rate pegs under different degrees of financial globalization. A first step in this direction consists in analyzing the impact of an increase in the degree of financial globalization for the dynamic of our economy. Recall that we interpret financial globalization as an increase in the parameter $\Omega$. As debt in this economy is denominated in foreign currency, exchange rate fluctuations will have an impact on the value of collateral and through this on the dynamic of foreign debt and of other macro variables. The higher is the degree of financial globalization, the higher is the destabilizing effect that exchange rate fluctuations have on foreign debt and the macro-economy. The combined effect of financial globalization and exchange rate fluctuations on foreign debt can be analyzed through the lenses of the following two effects:

1) Wedge/substitution effect. Consider an expected exchange rate appreciation. A fall in the exchange rate should increase the future value of collateral relative to the value of debt services, as shown by the collateral constraint, $R_{t}^{n, *} b_{t}^{*} \leq \Omega_{t} E_{t}\left\{\frac{\pi_{t+1} Z_{t+1} D_{t}}{\frac{e_{t+1}}{e_{t}}}\right\}$. As it stands clear from equation 13, when an additional unit of collateral becomes available the shadow value of relaxing the liability constraint, $\Omega U_{c, t} \xi_{t} E_{t}\left\{\frac{\pi_{t+1} Z_{t+1}}{\frac{e_{t+1}}{e_{t}}}\right\}$, changes. This shadow value represents an intertemporal distortion in the value of durable consumption between two different dates. Such wedge behaves as a tax on durable goods and changes in its magnitude can shift consumption from durable to non-durable goods at the current date. An increase in the paramter $\Omega$ has both a direct and an indirect impact on this wedge. Those two effects move actually in opposite directions. The direct impact comes form the fact that the size of the wedge itself depends upon $\Omega$. A higher value of 
this parameter increases credit availability therefore acting as a positive wealth shock that reduces the demand for collateralizable durable goods. In other words an increase in $\Omega$ increases the tax on durable good, $\Omega U_{c, t} \xi_{t} E_{t}\left\{\frac{\pi_{t+1} Z_{t+1}}{\frac{e_{t+1}}{e_{t}}}\right\}$, as it reduces the marginal benefit of durable relative to non-durable at the current date. The indirect impact comes from the fact that a higher value of $\Omega$, by relaxing the borrowing limit, reduces the size of $\xi_{t}$. As the shadow value of the borrowing limit decreases the marginal benefit of one additional unit of collateral today increases. As $\xi_{t}$ enter the durable tax component, a decrease in the lagrange multiplier will induce agents to substitute non-durable with durable consumption goods. Quantitatively the first effect seems to prevail, as, while the sensitivity of non-durable consumption increases when $\Omega$ increases, the contrary is true for the demand in durable goods. The increase in consumption volatility feeds into output and inflation, therefore destabilizing the whole economy.

3) Valuation effect. An exchange rate appreciation, by increasing the real value of collateral, increases the borrowing capacity at the extensive margin. Such valuation effect works in the same direction as the wealth effect, hence overall it tends to increase non-durable consumption volatility. This in turn increases the volatility of output and inflation as discussed previously.

Overall, it seems that increasing financial globalization tends to exacerbate the effects of exchange rate fluctuations and to destabilize the whole economy. Having established such link, the policy maker in our economy faces a trade-off in terms of inflation versus exchange rate targeting. On the one side, an exchange rate peg, accompanied to an increase in capital flows, tends to reduce the ability of the monetary authority to stabilize output and inflation. Such an effect, first formalized in the Mundell-Fleming model, is known as the impossible trinity. On the other side, higher financial globalization tends to exacerbate the destabilizing effects of exchange rate fluctuations on the whole economy and, because of this, calls for more aggressive exchange rate target. In our model the second effect tends to prevail as shown in Figure 9, 9 and 9. The three figures show the volatility (in percentage values) of output, inflation and (non-durable) consumption for different degrees of financial globalization and exchange rate target. To compute volatility we consider all three shocks (productivity, government expenditure and foreign interest rate). The figures show that the volatility of the three variables considered increases whenever the degree of financial globalization increases and decreases whenever the monetary authority increases the 
weight on exchange rates. The monetary authority can minimize the volatility of all three variables by applying an exchange rate target around 0.8 .

\section{Optimal Exchange Rate Policy}

We now turn to the design of the optimal policy plan which involves also the determination of the optimal exchange rate policy. We proceed in two steps. First, we highlight the role of wedges and trade-offs in our framework. We then compare the constrained pareto optimum solution and the competitive equilibrium for a simplified economy. Finally we examine the quantitative properties of the optimal plan; we focus on the optimal volatility of the exchange rate.

\subsection{The Policy Trade-offs and the Constrained Pareto Optimum}

Our model economy features two set of distortions. The first set includes all nominal distortions, which are given by price adjustment costs in both production sectors, $\frac{\omega_{d}}{2}\left(\pi_{d, t}-1\right)^{2}$ and $\frac{\omega}{2}\left(\pi_{h, t}-1\right)^{2}$. Nominal distortions entail a gap between the flexible price allocation and the sticky price allocation and can be offset by setting net inflation equal to zero in both sectors. This outcome can also be achieved by setting to zero the change in the domestic aggregate price index $P_{I, t}$. The second set of distortions are given by two wedges associated with the collateral constraints. The first is a wedge on the marginal rate of substitution between non-durable consumption at two different dates, while the second is a wedge on the marginal rate of substitution between durable and non-durable goods. Both wedges can be affected by the policy makers via the manipulation of the nominal exchange rate. Let's examine those wedges more closely.

Let's define $R_{t}^{c}=\frac{U_{c, t}}{\beta E_{t}\left\{U_{c, t+1} \frac{e_{t+1}}{e_{t}} \frac{1}{\pi_{t+1}}\right\}}$ as the households' intra-temporal price of consumption. When the constraint, (9), binds, households face the following endogenous finance premium:

$$
\frac{E_{t}\left\{R_{t}^{c}-R_{t}^{n *}\right\}}{R_{t}^{n *}}=\frac{U_{c, t} \xi_{t}}{\beta E_{t}\left\{U_{c, t+1} \frac{e_{t+1}}{e_{t}} \frac{1}{\pi_{t+1}}\right\}}
$$

This implies that it is now more costly and that a higher premium is required to perform a shift in consumption between two different dates. The premium is, indeed, a wedge between the marginal rate of substitution on consumption at two different dates and the rate of return on safe assets. The policy maker would like to offset this distortion in the long run and reduce its 
fluctuations in the short run. As fluctuations in the finance premium are related to fluctuations in the exchange rate and in the CPI inflation rate, one way to achieve such a goal is to target the exchange rate. Recall that also fluctuations in the CPI are linked to fluctuations in the real exchange rate, as shown by equation 18 .

The second wedge, induced by the presence of the collateral constraint, affects the marginal rate of substitution between durable and non-durable goods, as summarized by equation 13, and is given by the following term:

$$
W e d g e_{c, d}=\Omega U_{c, t} \xi_{t} E_{t}\left\{\frac{\pi_{t+1} Z_{t+1}}{\frac{e_{t+1}}{e_{t}}}\right\}
$$

Notice that the size and the fluctuations of this wedge can be reduced by targeting the nominal exchange rate alongside with the CPI. To summarize, both wedges can be offset by controlling movements in the exchange rate.

Overall the policy maker would like to smooth fluctuations in foreign lending, as they reduce the extent to which households can improve their consumption smoothing possibilities. As explained before, fluctuations in foreign lending are jointly determined by equations 30 and 9 . Both equations highlight a clear link between fluctuations in external debt and the nominal exchange rate.

Generally speaking the policy maker is confronted with the following trade-off: on the one side nominal rigidities require focusing on stabilization of domestic inflation, with no attention to fluctuations in the nominal exchange rate, on the other side, wedges associated with the presence of collateral constraints, can be made inoperative by targeting the nominal exchange rate.

It is important to notice that the policy maker does not face any incentive to use exchange rate fluctuations to render state contingent the collateral constraint. This would, indeed, be the case if the foreign debt was limited by a constant: the policy maker could use fluctuations in the exchange rate to ease the borrowing constraints in times of negative shocks. On the contrary, the collateral constraint is state contingent by construction, hence the policy maker only faces an incentive to smooth fluctuations in the value of external debt.

To highlight the role of the collateral constraint for the design of optimal monetary policy it is instructive to derive the constrained pareto optimal allocation for the economy under flexible prices. In this case all (gross) inflation rates are set equal to one and the change in the nominal 
exchange rate can be written as follows: $\frac{e_{t+1}}{e_{t}}=\frac{q_{t+1}}{q_{t}}=\frac{g\left(S_{t+1}\right)}{g\left(S_{t}\right)}$. To simplify calculations, it is also assumed that adjustment costs on durables are zero. Under those assumptions, the planner of the small open economy maximizes households utility subject to the current account dynamic given by equation 30 , to the collateral constraints, 9 , and to the accumulation of durable goods, $X_{t}=D_{t}-(1-\delta) D_{t-1}$. For given foreign real interest rate, $R_{t}^{*}$, the planner optimization problem reads as follows:

$$
\operatorname{Max}_{C_{t}, D_{t}, b_{t}^{*}, S_{t}} E_{t}\left\{\sum_{t=0}^{\infty} \beta^{t} U\left(C_{t}, D_{t}, N_{t}\right)\right\}
$$

subject to the resource constraint given by equation 30, the collateral constraint given by equation 9 and the equation for the accumulation of durable goods, $X_{t}=D_{t}-(1-\delta) D_{t-1}$. Let's define $\mu_{t}$ as the Lagrange multiplier on $30, \xi_{t}$ as the Lagrange multiplier on the collateral constraint, $9, \zeta_{t}$, as the Lagrange multiplier on the accumulation of durable. Furthermore, it is convenient to define the following functions: $h\left(S_{t}\right)=\frac{(1-\alpha) S_{t}^{\eta}}{\left[\left(\alpha+(1-\alpha) S_{t}^{1-\eta}\right)\right]^{\frac{1}{1-\eta}}}$ and $k\left(S_{t}\right)=\frac{(1-\alpha) S_{t}^{1-\eta}}{\left(\alpha+(1-\alpha) S_{t}^{1-\eta}\right)}$. First order conditions with respect to the following set of variables $C_{t}, D_{t}, b_{t}^{*}, S_{t}$ read as follows:

$$
\begin{gathered}
U_{c, t}-\mu_{t} k\left(S_{t}\right)=0 \\
U_{D, t}-\xi_{t} \Omega E_{t}\left\{\frac{Z_{t+1}}{\left.\frac{g\left(S_{t+1}\right)}{g\left(S_{t}\right)}\right\}=0}\right. \\
\mu_{t}-E_{t}\left(\mu_{t+1} \beta R_{t}^{*} \frac{g\left(S_{t+1}\right)}{g\left(S_{t}\right)}\right)+\xi_{t} R_{t}^{*}=0 \\
\mu_{t} \Omega E_{t}\left\{\frac{Z_{t+1} D_{t}}{g\left(S_{t+1}\right) R_{t}^{*}}\right\} g^{\prime}\left(S_{t}\right)+\mu_{t-1} \Omega E_{t-1}\left\{\frac{Z_{t} D_{t-1} g\left(S_{t-1}\right)}{R_{t-1}^{*}}\right\} \frac{1}{g\left(S_{t}\right)^{2}} g^{\prime}\left(S_{t}\right)-\mu_{t} h^{\prime}\left(S_{t}\right)-\mu_{t} k^{\prime}\left(S_{t}\right)=0
\end{gathered}
$$

Merging equations 37, 38 and 39 delivers:

$$
\frac{U_{D, t}}{U_{c, t}}=[(1-\delta) \beta] E_{t}\left\{\zeta_{t+1}\right\}-\Omega \beta E_{t}\left\{Z_{t+1} \frac{U_{c, t+1}}{U_{c, t}} \frac{k\left(S_{t}\right)}{k\left(S_{t+1}\right)}\right\}-\zeta_{t}+\frac{\Omega}{k\left(S_{t}\right) R_{t}^{*}} E_{t}\left\{Z_{t+1} \frac{g\left(S_{t}\right)}{g\left(S_{t+1}\right)}\right\}
$$

The corresponding competitive equilibrium faces a marginal rate of substitution between durable and non-durable consumption which reads as follows:

$$
\frac{U_{D, t}}{U_{c, t}}=[(1-\delta) \beta-\Omega \beta] E_{t}\left\{Z_{t+1} \frac{U_{c, t+1}}{U_{c, t}}\right\}-Z_{t}-\frac{\Omega}{R_{t}^{*}} E_{t}\left\{Z_{t+1} \frac{g\left(S_{t}\right)}{g\left(S_{t+1}\right)}\right\}
$$


Two considerations arise. First, one condition for the equivalence between the competitive economy and the constraint pareto optimal allocation is obtained by setting, at each point in time, the value of one unit of durable consumption, measured in utils, equal to the shadow value of durable goods, namely $\zeta_{t}=Z_{t} U_{c, t}$. The comparison between the marginal rate of substitution in the planner economy and the competitive economy sheds light on the planner behavior, who internalizes the effects that changes in the relative prices across countries have on the value of collateral and on the marginal rate of substitution between durable and non-durable consumption.

\subsection{Quantitative Properties of the Ramsey (Optimal) Monetary Policy}

Given that higher financial globalization tends to exacerbate the destabilizing effects of exchange rate fluctuations, should the monetary authority optimally stabilize the exchange rate? In models with sticky prices, the main distortion faced by the monetary authority is given by the cost of inflation fluctuations. Nominal frictions call for pure inflation targeting, with no weight assigned to either output fluctuations or to exchange rate fluctuations. This is the prescription advanced both in closed ${ }^{12}$ and open economy model ${ }^{13}$. However in our model the planner faces a trade-off between stabilizing inflation and stabilizing the exchange rate, as, in presence of high financial globalization, the latter exacerbates inefficient fluctuations in consumption. Hence the planner might want to deviate from full price stability and trade-offs inflation volatility with exchange rate stabilization.

We analyze the design of optimal monetary policy following the Ramsey approach ${ }^{14}$. The optimal policy is determined by a monetary authority that maximizes the discounted sum of utilities of all agents given the constraints of the competitive economy. The Lagrangian describing the optimal plan can be constructed following two alternative approaches. The first is the primal approach which amounts at describing the competitive equilibrium in terms of a minimal set of relations involving only real allocations, in the spirit of the primal approach described in Lucas and Stokey [55]. In the presence of sticky prices and borrowing constraints it is not possible to reduce the planner's problem to a maximization problem with a single implementability constraint.

\footnotetext{
${ }^{12}$ See Woodford [85], Clarida, Gali and Gertler [24] among others.

${ }^{13}$ See for instance Obsteld and Rogoff [67], Benigno and Benigno [12], McCallum and Nelson [58], Corsetti and Pesenti [28] and [28], Kollman [49], Devereux and Engel [31], Clarida, Galí, and Gertler [25], Galí and Monacelli [38].

${ }^{14}$ See Ramsey [72], Atkinson and Stiglitz [3], Lucas and Stokey [55], Chari and Kehoe [?], Khan et al.[47], SchmittGrohe and Uribe [74] among many others.
} 
Hence we follow the alternative approach, which consists in maximizing agents' utility subject to the full set of competitive economy equilibrium conditions and by keeping all prices. The optimal policy plan for the domestic economy is determined by a monetary authority that maximizes the discounted sum of utilities of all domestic residents:

$$
\operatorname{Min}_{\left\{\Lambda_{t}^{n}\right\}_{t=0}^{\infty}} \operatorname{Max}_{\left\{\Xi_{t}^{n}\right\}_{t=0}^{\infty}} E_{0}\left\{\sum_{t=0}^{\infty} \beta^{t} U\left(C_{I, t}, N_{t}\right)\right\}
$$

given the constraints of the competitive economy represented by equations $5,9,10,11,12,13,16$, $17,18,19,21,22,24,25,26,27$.

As constraints 9, 11, 12, 13, 16, 21, 22, 27 exhibit future expectations of control variables, the maximization problem of the Ramsey planner is intrinsically non-recursive. As first emphasized in Kydland and Prescott [50], and then developed by Marcet and Marimon [56], a formal way to rewrite the same problem in a recursive stationary form is to enlarge the planner's state space with additional (pseudo) co-state variables. Such variables bear the crucial meaning of tracking, along the dynamics, the value to the planner of committing to the pre-announced policy plan.

The optimal monetary policy response to shocks is computed using second order approximations $^{15}$ of the first order conditions for the recursively stationary Lagrangian problem that characterizes the Ramsey plan. Technically one needs to compute the stationary allocation that characterizes the deterministic steady state of the first order conditions to the Ramsey plan. One can then compute a second order approximation of the respective policy functions in the neighborhood of the same steady state ${ }^{16}$. This amounts to implicitly assuming that the economy has been

\footnotetext{
${ }^{15}$ Second order approximation methods have the particular advantage of accounting for the effects of volatility of variables on the mean levels. See among others, K. Judd, developed by C. Sims [80], S. Schmitt-Grohe and M. Uribe [79], F. Collard and M. Juillard [44].

${ }^{16}$ Let's assume that the system of Ramsey first order conditions takes the following form:
}

$$
E_{t}\left\{f\left(y_{t+1}, y_{t}, y_{t-1}, u_{t} ; \theta\right)\right\}=0
$$

where $y_{t}$ is the vector of endogenous variables (which includes both forward looking variables and pre-determined), $u_{t}$ is the vector of exogenous shocks, $\theta$ is vector of parameters. Let's further assume that the policy function takes the following form:

$$
y_{t}=g\left(y_{t-1}, u_{t}, \sigma\right)
$$

The actual policy function can then be computed using the following approximation:

$$
\begin{aligned}
y_{t}= & \bar{y}+0.5 g_{\sigma \sigma} \sigma^{2}+g_{y} \hat{y}+g_{u} u+0.5\left(g_{y y}(\hat{y} \otimes \hat{y})\right. \\
& \left.+g_{\mathrm{uu}}(u \otimes u)\right)+g_{y u}(\hat{y} \otimes u)
\end{aligned}
$$

in which partial derivatives are obtained from the second order Taylor expansion of the system in 43. 
evolving and policy has been conducted around such a steady already for a long period of time (in a timeless perspective).

To analyze the trade-off between inflation and exchange rate stabilization the Ramsey plan is simulated under the three shocks considered in order to compute the implied optimal volatility of real exchange rate and inflation.

Figure 9 shows results by plotting the optimal volatility (in percentage values) of real exchange rate and of (annual) inflation for different values of the degree of financial globalization. While the volatility of the real exchange rate is largely stabilized for increasing values of the financial openness, the volatility of inflation is instead increasing significantly. Hence, when the economy becomes more financially globalized the trade-off between inflation and exchange rate stabilization moves in favor of the latter. This is so since the wedges, induced by the presence of the collateral constraints, become larger and more volatile, hence the policy maker faces a stronger incentive to abate fluctuations in those wedges, a goal which is achieved by fine tuning movements in the exchange rates.

\section{Conclusions}

We have analyzed an economy in which consumption is financed through foreign lending. Net lending toward the rest of the world is constrained by a borrowing limit motivated by limited enforcement and borrowing is secured by collateral in the form of durable goods. We demonstrate that although this economy can generate persistent current account deficit it can still deliver a stationary equilibrium. As financial globalization tends to exacerbate the destabilizing effects of exchange rate fluctuations, the monetary authority can achieve higher stabilization and welfare by stabilizing the exchange rate. This implies that pure inflation targeting strategies might not be fully optimal for economies with large exposure to foreign debt and significant global imbalances, a condition which characterized several industrialized countries in the last decade. 


\section{Appendix 1. Net asset accumulation and current account}

The market clearing condition for the non-durable sector in the small open economy reads as follows:

$$
A_{h, t} N_{h, t}=\alpha\left[\left(\alpha+(1-\alpha) S_{t}^{1-\eta}\right)\right]^{\frac{\eta}{1-\eta}} C_{t}+(1-\alpha)\left(\frac{1}{S_{t}}\right)^{-\eta} C_{t}^{*}+\frac{\omega}{2}\left(\pi_{h, t}-1\right)^{2}+g_{t}
$$

After imposing the government budget constraint, the budget constraint of the borrowers in the small open economy reads as follows:

$$
C_{t}+R_{t-1}^{n, *} \frac{e_{t}}{e_{t-1}} \frac{b_{t-1}^{*}}{\pi_{t}}+Z_{t}\left(D_{t}-D_{t-1}(1-\delta)\right)=\frac{W_{t}}{P_{t}} N_{t}+b_{t}^{*}+\frac{\Pi_{h, t}}{P_{t}}+\frac{\Pi_{d, t}}{P_{t}}-g_{t}
$$

Let's re-define aggregate profits as $\Pi_{h, t}+\Pi_{d, t}=\Gamma$ which read as:

$$
\Gamma=P_{t} A_{h, t} N_{h, t}+P_{d, t} A_{d, t} N_{d, t}-W_{t} N_{t}-P_{d, t} \frac{\omega_{d}}{2}\left(\pi_{d, t}-1\right)^{2}-P_{h, t} \frac{\omega}{2}\left(\pi_{h, t}-1\right)^{2}
$$

which in real terms becomes:

$$
\frac{\Gamma}{P_{t}}=\left(\frac{P_{h, t}}{P_{t}}\right) A_{h, t} N_{h, t}+Z_{t} A_{d, t} N_{d, t}-\frac{W_{t} N_{t}}{P_{t}}-Z_{t} \frac{\omega_{d}}{2}\left(\pi_{d, t}-1\right)^{2}-\left(\frac{P_{h, t}}{P_{t}}\right) \frac{\omega}{2}\left(\pi_{h, t}-1\right)^{2}+g_{t}
$$

Since $A_{h, t} N_{h, t}$ is given by equation 44 we obtain:

$$
\begin{aligned}
\frac{\Gamma}{P_{t}}= & \left(\frac{P_{h, t}}{P_{t}}\right)\left[\alpha\left[\left(\alpha+(1-\alpha) S_{t}^{1-\eta}\right)\right]^{\frac{\eta}{1-\eta}} C_{t}+(1-\alpha)\left(\frac{1}{S_{t}}\right)^{-\eta} C_{t}^{*}+\frac{\omega_{d}}{2}\left(\pi_{h, t}-1\right)^{2}\right]+g_{t}+ \\
& +Z_{t} A_{d, t} N_{d, t}-\frac{W_{t} N_{t}}{P_{t}}-Z_{t} \frac{\omega_{d}}{2}\left(\pi_{d, t}-1\right)^{2}-\left(\frac{P_{h, t}}{P_{t}}\right) \frac{\omega}{2}\left(\pi_{h, t}-1\right)^{2}
\end{aligned}
$$

Moreover using the market clearing condition for the durable sector, as from equation 25, one obtains:

$$
\begin{aligned}
\frac{\Gamma}{P_{t}}= & \left(\frac{P_{h, t}}{P_{t}}\right)\left[\alpha\left[\left(\alpha+(1-\alpha) S_{t}^{1-\eta}\right)\right]^{\frac{\eta}{1-\eta}} C_{t}+(1-\alpha)\left(\frac{1}{S_{t}}\right)^{-\eta} C_{t}^{*}\right]+g_{t}+ \\
& +Z_{t}\left[D_{t}-(1-\delta) D_{t-1}\right]-\frac{W_{t} N_{t}}{P_{t}}
\end{aligned}
$$


Substitute the latter expression into the households budget constraint leads to:

$$
\begin{aligned}
0= & C_{t}+Z_{t}\left[D_{t}-(1-\delta) D_{t-1}\right]+R_{t-1}^{n, *} \frac{e_{t}}{e_{t-1}} \frac{b_{t-1}^{*}}{\pi_{t}}-b_{t}^{*}-\frac{W_{t} N_{t}}{P_{t}} \\
& -\left[\left(\frac{P_{h, t}}{P_{t}}\right)\left[\alpha\left(\alpha+(1-\alpha) S_{t}^{1-\eta}\right)^{\frac{\eta}{1-\eta}} C_{t}+(1-\alpha)\left(\frac{1}{S_{t}}\right)^{-\eta} C_{t}^{*}\right]+Z_{t}\left[D_{t}-(1-\delta) D_{t-1}\right]-\frac{W_{t} N_{t}}{P_{t}}\right]
\end{aligned}
$$

Finally after some manipulation and using the expression for the price index, $P_{t}=P_{h, t}\left[\left(\alpha+(1-\alpha) S_{t}^{1-\eta}\right)\right]^{\frac{1}{1-\eta}}$ leads to:

$$
R_{t-1}^{n, *} \frac{e_{t}}{e_{t-1}} \frac{b_{t-1}^{*}}{\pi_{t}}-b_{t}^{*}=(1-\alpha) C_{t}^{*} \frac{S_{t}^{\eta}}{\left[\left(\alpha+(1-\alpha) S_{t}^{1-\eta}\right)\right]^{\frac{1}{1-\eta}}}-C_{t}(1-\alpha) \frac{S_{t}^{1-\eta}}{\left(\alpha+(1-\alpha) S_{t}^{1-\eta}\right)}
$$

which states that the flow of external debt must equate net exports. 


\section{References}

[1] Aiyagari, S. Rao (1994). "Uninsured idiosyncratic risk, and aggregate saving." Quarterly Journal of Economics, 109, 659-684.

[2] Aoki, Kosuke, Gianluca, Benigno and Nobu Kiyotaki, (2005). "Adjusting to Capital Liberalization". Mimeo.

[3] Atkinson, Anthony B. and Joseph Stiglitz, (1976). "The Design of Tax Structure: Direct Versus Indirect Taxation", Journal of Public Economics, 6, 1-2, 55-75.

[4] Attanasio, Orazio P. , Goldberg, Pinelopi K. and Ekaterini Kyriazidou (2008). "Credit Constraints in the Market for Consumer Durables: Evidence from Micro Data on Car Loans". International Economic Review, 401-36.

[5] Backus, David, Espen Henricksen, Frederic Lambert and Chris Telmer, (2005). "Current Account Fact and Fiction". Mimeo.

[6] Backus, David and Patrick, Kehoe, (1989). "International Evidence on the Historical Properties of the Business Cycles". W.p. 402R, Federal Reserve Bank of Minneapolis, Research Department.

[7] Backus, David K., Kehoe Patrick J. and Kydland, Finn E. (1992). "International Real Business Cycles". Journal of Political Economy, 101, 745-775.

[8] Barsky, Robert, Christopher House and Miles Kimball, (2005). "Sticky Price Models and Durable Goods". American Economic Review, 97(3), 984-998.

[9] Becker, Robert A, (1980). "On the Long-Run Steady State in a Simple Dynamic Model of Equilibrium with Heterogeneous Households." Quarterly Journal of Economics, 95 (2), 1980, $375-382$.

[10] Becker, Robert A. and Foias, Ciprian, (1987). "A characterization of Ramsey equilibrium". Journal of Economic Theory, vol. 41(1), 173-184. 
[11] Becker, Robert A. and Foias, Ciprian, (1994). "The Local Bifurcation of Ramsey Equilibrium." Economic Theory, vol. 4(5), 719-44.

[12] Benigno, Pierpaolo and Gianluca Benigno, (2003). "Price Stability Open Economies", Review of Economic Studies, 60,4.

[13] Benigno, Gianluca, Benigno Pierpaolo and Fabio Ghironi, (2007). "Interest Rate Rules for Fixed Exchange Rate Regimes." Journal of Economic Dynamics and Control, 31(7), 21962211.

[14] Benigno, Gianluca, Huigang Chen, Christopher Otrok, Alessandro Rebucci, Eric Young, (2010). "Revisiting Overborrowing and Its Policy Implications". Mimeo.

[15] Bernanke, Ben, (2005). "The global saving glut and the US current account deficit". The Federal Reserve Board.

[16] Bils M. and P. Klenow, (2004). "Some Evidence on the Importance of Sticky Prices." Journal of Political Economy, October.

[17] Black, J.M., de Meza, D., Jeffreys, D., (1996). "House prices, the supply of collateral and the enterprise economy." Economic Journal.

[18] Broner, Fernando and Ventura, Jaume, (2008). "Rethinking the effects of financial liberalization." Economics Working Papers 1128, Department of Economics and Business, Universitat Pompeu Fabra.

[19] Campbell, Jeffrey Y. and Zvi Hercowitz, (2006). "The Role of Collateralized Household Debt in Macroeconomic Stabilization". NBER w.p. 11330.

[20] Carlstrom, Charles and Timothy Fuerst, (2006). "Co-movement in Sticky Price Models with Durable Goods". Mimeo.

[21] Chang, Robert, Cespedes, Luis and Andre Velasco, (2004). "Balance Sheets and Exchange Rate Policy", American Economic Review. 
[22] Chari, Varadarajan V. and Patrick J. Kehoe, (1999). "Optimal Fiscal and Monetary Policy", in Handbook of Macroeconomics, M. Woodford and J. Taylor Eds., North Holland.

[23] Chari, V.V., Kehoe, Patrick J. and McGrattan, Ellen R., (2005). "Sudden Stops and Output Drops". American Economic Review Papers and Proceedings.

[24] Clarida, Richard, Jordi Gali, and Mark Gertler, (2000). Monetary Policy Rules and Macroeconomic Stability: Evidence and Some Theory. Quarterly Journal of Economics, 115 (1), $147-180$.

[25] Clarida, Richard, Jordi Galí, and Mark Gertler (2002). "A Simple Framework for International Monetary Policy Analysis." Journal of Monetary Economics, vol. 49, no. 5, 879-904.

[26] Cole, Harald and Maurice Obstfeld, (1989). "Commodity Trade and International Risk Sharing: How Much Do Financial Markets Matter". Journal of Monetary Economics, 28(1), 3-24.

[27] Corsetti, Giancarlo and Paolo Pesenti, (2001). "Welfare and Macroeconomic Interdependence". Quarterly Journal of Economics.

[28] Corsetti, Giancarlo and Paolo Pesenti, (2003). "International Dimensions of Optimal Monetary Policy", Journal of Monetary Economics.

[29] Davis, Morris and Jonathan, Heatcote, (2005). "Housing and the Business Cycle". International Economic Review, 46(3), 751-784.

[30] Deaton, Angus, (1991). "Saving and Liquidity Constraints". Econometrica, 59, 1221-1248.

[31] Devereux, Michael B. and Charles Engel, (2003). "Monetary Policy in the Open Economy Revisited: Exchange Rate Flexibility and Price Setting Behavior," Review of Economic Studies, 60, 765-783.

[32] Devereux, Michael B. and Alan Sutherland, (2007). "Monetary Policy and Portfolio Choice in an Open Economy Macro Model." Journal of the European Economic Association, MIT Press, vol. 5(2-3), pages 491-499, 04-05. 
[33] Erceg, Chris and Andrew Levin, (2005). "Optimal Monetary Policy with Durable Consumption Goods". International finance Discussion Paper 748, Board of Governors.

[34] Faia, Ester (2007), "Finance and International Business Cycles", Journal of Monetary Economics.

[35] Faia, Ester and Tommaso, Monacelli, (2008). "Optimal Monetary Policy in A Small Open Economy with Home Bias". Journal of Money, Credit and Banking,vol. 40, pages 721-750.

[36] Friedman, Milton, (1959). "The Optimum Quantity of Money", in The Optimum Quantity of Money, and Other Essays, Aldine Publishing Company, Chicago.

[37] Galí, Jordi and Mark Gertler, (1999). "Inflation Dynamics: A Structural Econometric Analysis". Journal of Monetary Economics, vol. 44, no 2, 195-222.

[38] Galí, Jordi and Tommaso Monacelli, (2005). "Monetary Policy and Exchange Rate Volatility in a Small Open Economy", Review of Economic Studies, vol. 72, issue 3, 2005, 707-734.

[39] Ghironi, Fabio, (2008). "The Role of Net Foreign Assets in a New Keynesian Small Open Economy Model". Journal of Economic Dynamics and Control (forthcoming).

[40] Gertler M., Gilchrist S. and F.M. Natalucci, (2007). "External Constraints on Monetary Policy and The Financial Accelerator", Journal of Money, Credit and Banking

[41] Iacoviello, Matteo, (2005). "House Prices, Borrowing Constraints and Monetary Policy in the Business Cycle". American Economic Review, 95(3), 739-764.

[42] Iacoviello, Matteo, and Raoul Minetti, (2006) "International Business Cycles with Domestic and Foreign Lenders". Journal of Monetary Economics, 53 (8), 2267-2282.

[43] Jappelli, Tullio and Marco Pagano, (1994). "Saving Growth and Liquidity Constraints". Quarterly Journal of Economics, 109, 83-109.

[44] Juilliard, Michel and Fabrice, Collard (2001). "A Higher-Order Taylor Expansion Approach to Simulation of Stochastic Forward-Looking Models with an Application to a Nonlinear Phillips Curve Model". Computational Economics, vol. 17, pp. 125-139. 
[45] Judd, Kenneth, (1998). Numerical Methods in Economics, Cambridge, MA, MIT Press.

[46] Kiyotaki, Nobuhiro and Moore, John. (1997) "Credit Cycle". Journal of Political Economy, 105(2), pp. 211-48.

[47] Khan, Aubhik, Robert King and Alexander L. Wolman, (2003). "Optimal Monetary Policy", Review of Economic Studies, 60,4.

[48] Kocherlacota, Narayana, (2000). "Creating Business Cycles Through Credit Constraints". Federal Reserve Bank of Minneapolis Quarterly Review, 24(3), 2-10.

[49] Kollmann, Robert, (2001). "The Exchange Rate in a Dynamic Optimizing Current Account Model with Nominal Rigidities: A Quantitative Investigation," Journal of International Economics vol.55, 243-262.

[50] Kydland, Finn and Edward C. Prescott, (1980). "Dynamic Optimal Taxation, Rational Expectations and Optimal Control". Journal of Economic Dynamics and Control 2:79-91.

[51] Krusell, Per and A. Smith, (1998). "Income and Wealth Heterogeneity in the Macroeconomy". Journal of Political Economy, 106, 867-896.

[52] Lahiri, A. R., R. Singh and Carlos Vegh, (2007). "Segmented Asset Markets and Optimal Exchange Rate Regimes", Journal of International Economics 72, 1-21.

[53] Lane, Philip, GianMaria Milesi-Ferretti, (2001). "The External Wealth of Nations: Estimates of Foreign Assets and Liabilities for Industrial and Developing Countries". Journal of International Economics, 55, 263-94.

[54] Levchenko, Andrei, (2005). "Financial Liberalization and Consumption Volatility in Developing Countries". IMF Staff Papers 52, 2.

[55] Lucas, Robert E. and Nancy Stokey, (1983). "Optimal Fiscal and Monetary Policy in an Economy Without Capital", Journal of Monetary Economics, 12:55-93.

[56] Marcet, Albert and Ramon Marimon, (1999). Recursive Contracts. Mimeo, Universitat Pompeu Fabra and European University Institute. 
[57] McCallum, Bennett and Edward Nelson, (2000). "An Optimizing IS-LM Specification for Monetary Policy and Business Cycle Analysis". Journal of Money, Credit and Banking, 31(3), 296-316.

[58] McCallum, Bennett and Edward Nelson, (2000). "Monetary Policy for an Open Economy: An Alternative Framework with Optimizing Agents and Sticky Prices", Oxford Review of Economic Policy 16, 74-91.

[59] Mendoza, Enrique G., (1991). "Real Business Cycle in a Small Open Economy". American Economic Review, 81(4), 797-818.

[60] Mendoza, Enrique, (2006). "Endogenous Sudden Stops in a Business Cycle Model with Collateral Constraints: A Fisherian Deflation of Tobin's Q". Manuscript, University of Maryland.

[61] Mendoza, Enrique, and Katherine, Smith, (2006). "Quantitative Implications of a Debt Deflation Theory of Sudden Stops and Asset Prices". Forthcoming Journal of International Economics.

[62] Mendoza, Enrique, Vincenzo Quadrini and Viktor Rios-Rull, (2007). "On the Welfare Implications of Financial Globalization without Financial Development". International Seminar on Macroeconomics.

[63] Mendoza, Enrique, Vincenzo Quadrini and Viktor Rios-Rull, (2009). "Financial Integration, Financial Deepness and Global Imbalances." Journal of Political Economy, 117(3).

[64] Miles, David, (1992). "Housing Markets, Consumption and Financial Liberalization in Major Economies". European Economic Review, 36, 1093-1127.

[65] Monacelli, Tommaso, (2009). "New Keynesian models, durable goods, and collateral constraints". Journal of Monetary Economics, Volume 56, Issue 2, Pages 137-282.

[66] Obstfeld, Maurice, and Kenneth Rogoff, (1995). "Exchange Rate Dynamics Redux". Journal of Political Economy, 103, 624-60. 
[67] Obstfeld Maurice and Kenneth Rogoff, (2000). "The Six Major Puzzles in International Macroeconomics: Is There a Common Cause?". Macroeconomics Annual, B. Bernanke and K. Rogoff eds.

[68] Perotti, Roberto, (2004). "Estimating the Effects of Fiscal Policy in OECD Countries". Mimeo.

[69] Perri, Fabrizio and Vincenzo Quadrini. (2008) "Understanding the International Great Moderation". Manuscript.

[70] Perri, Fabrizio, (2007). "Default and Enforcement Constraints". The New Palgrave Dictionary in Economics.

[71] Prescott, Edward, (1986). "Theory Ahead of Business Cycle Measurement". Carnegie Rochester Series on Public Policy, 24:11-44.

[72] Ramsey, Frank P., (1927). "A contribution to the Theory of Taxation". Economic Journal, $37: 47-61$.

[73] Sbordone, Argia (2002). "Prices and Unit Labor Costs: A New Test of Price Stickiness". Journal of Monetary Economics Vol. 49 (2).

[74] Schmitt-Grohe, Stephanie and Martin Uribe (2004). "Optimal Fiscal and Monetary Policy under Sticky Prices", Journal of Economic Theory, 114,198-230.

[75] Rotemberg, Julio, (1982). "Monopolistic Price Adjustment and Aggregate Output". Review of Economics Studies, 44, 517-531.

[76] Rudebusch, Glenn (2002). "Term Structure Evidence on Interest Rate Smoothing and Monetary Policy Inertia." Journal of Monetary Economics, Vol. 49, pp. 1161-1187.

[77] Rudebusch, Glenn (2006). "Monetary Policy Inertia: Fact or Fiction?" International Journal of Central Banking, Vol. 2, No. 3, pp. 85-135.

[78] Schmitt-Grohe, Stephanie and Uribe, Martin, (2003). "Closing Small Open Economy Models". Journal of International Economics, 61, 163-185. 
[79] Schmitt-Grohe, S., Uribe, M. (2004a). " Solving Dynamic General Equilibrium Models Using a Second-Order Approximation to the Policy Function". Journal of Economic Dynamics and Control 28, 645-858.

[80] Sims, Christopher, "Second Order Accurate Solution of Discrete Time Dynamic Equilibrium Models." Manuscript. Princeton: Princeton University,

[81] December 2000b.

[82] Sutherland, Alan, (2002). "International Monetary Policy Coordination and Financial Market Integration" CEPR Discussion Paper No 4251.

[83] Topel, Robert and Sherwin Rosen, (1988). "Housing Investment in the United States". Journal of Political Economy, 96(4).

[84] Uribe, Martin. (2006) "On Overborrowing". American Economic Review Papers and Proceedings, 86, 417-421.

[85] Woodford, Michael (2003). Interest and Prices. Princeton University Press.

[86] Zeldes, Stephen, (1989). "Consumption and Liquidity Constraints". Journal of Political Economy, $97,305-346$. 

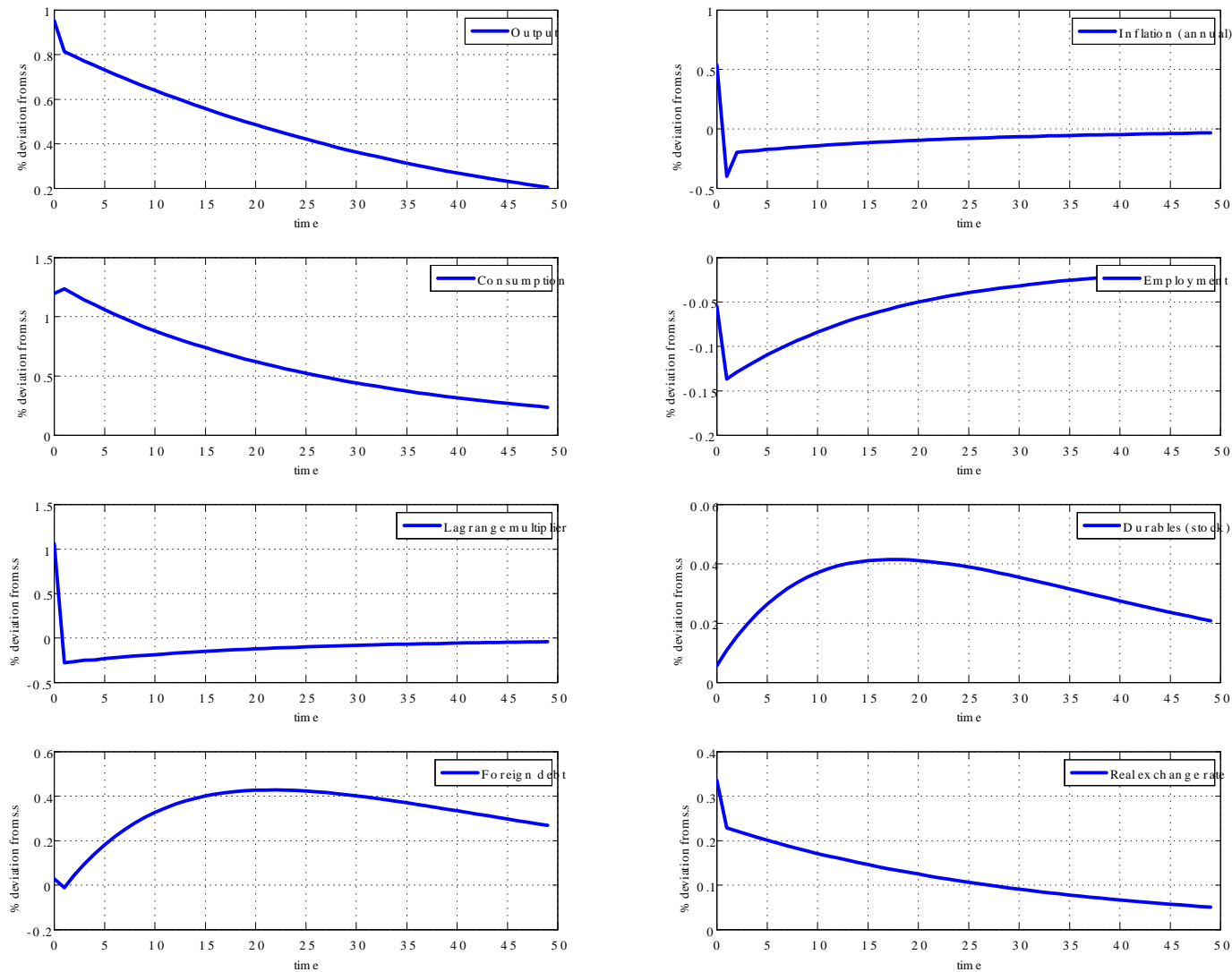

Figure 1: Impulse responses to domestic productivity shock 

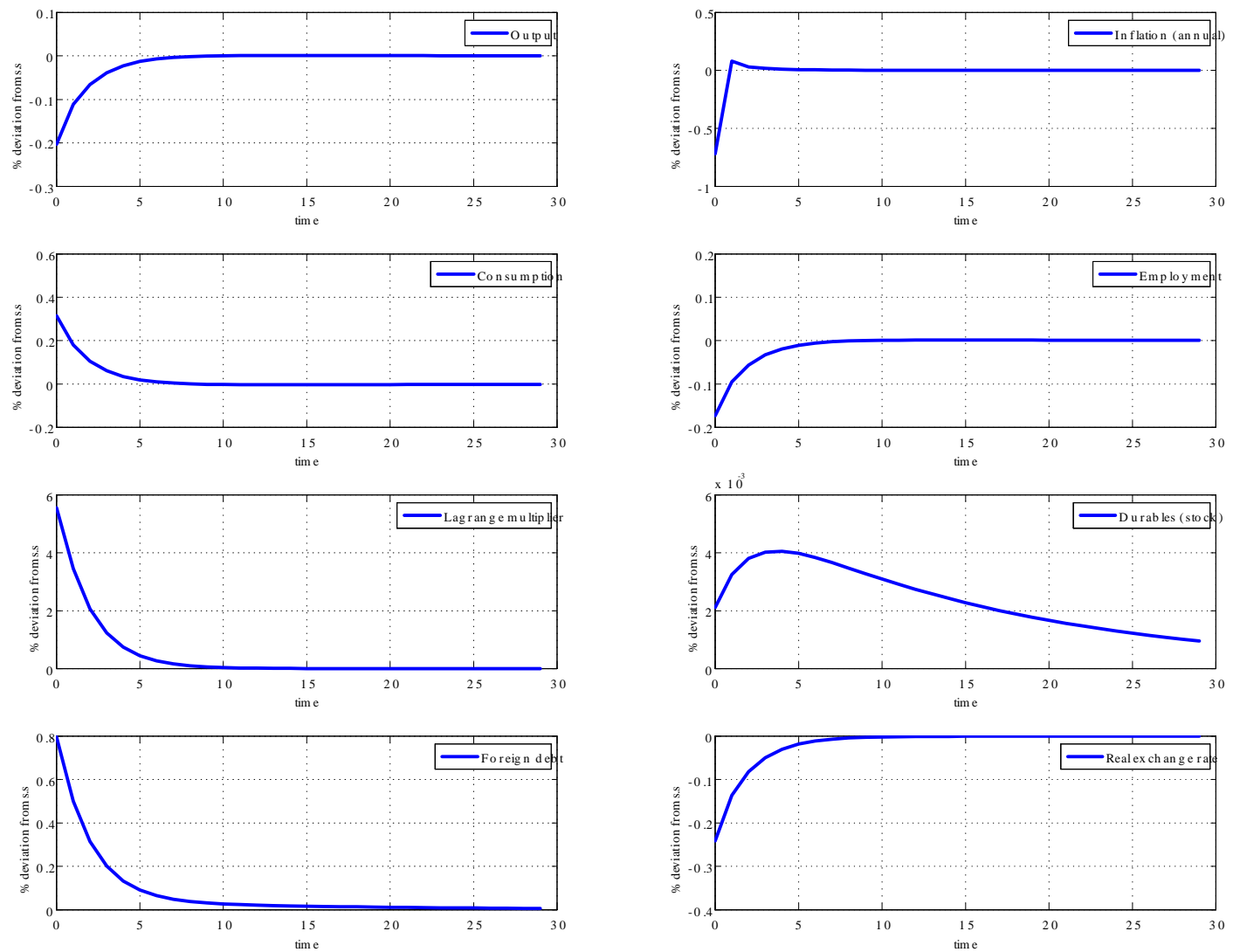

Figure 2: Impulse responses to global liquidity shock (a fall in foreign interest rates). 


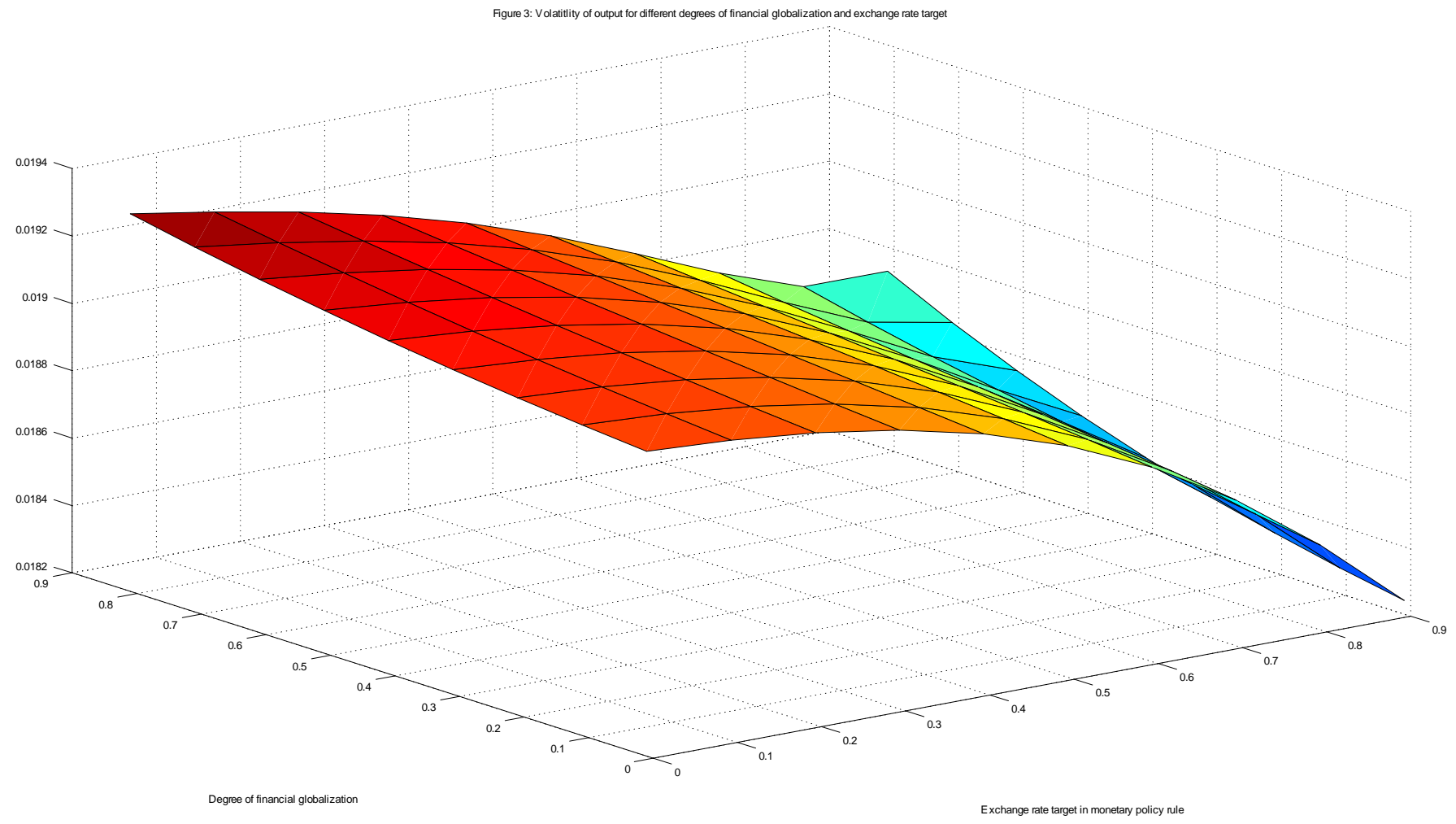




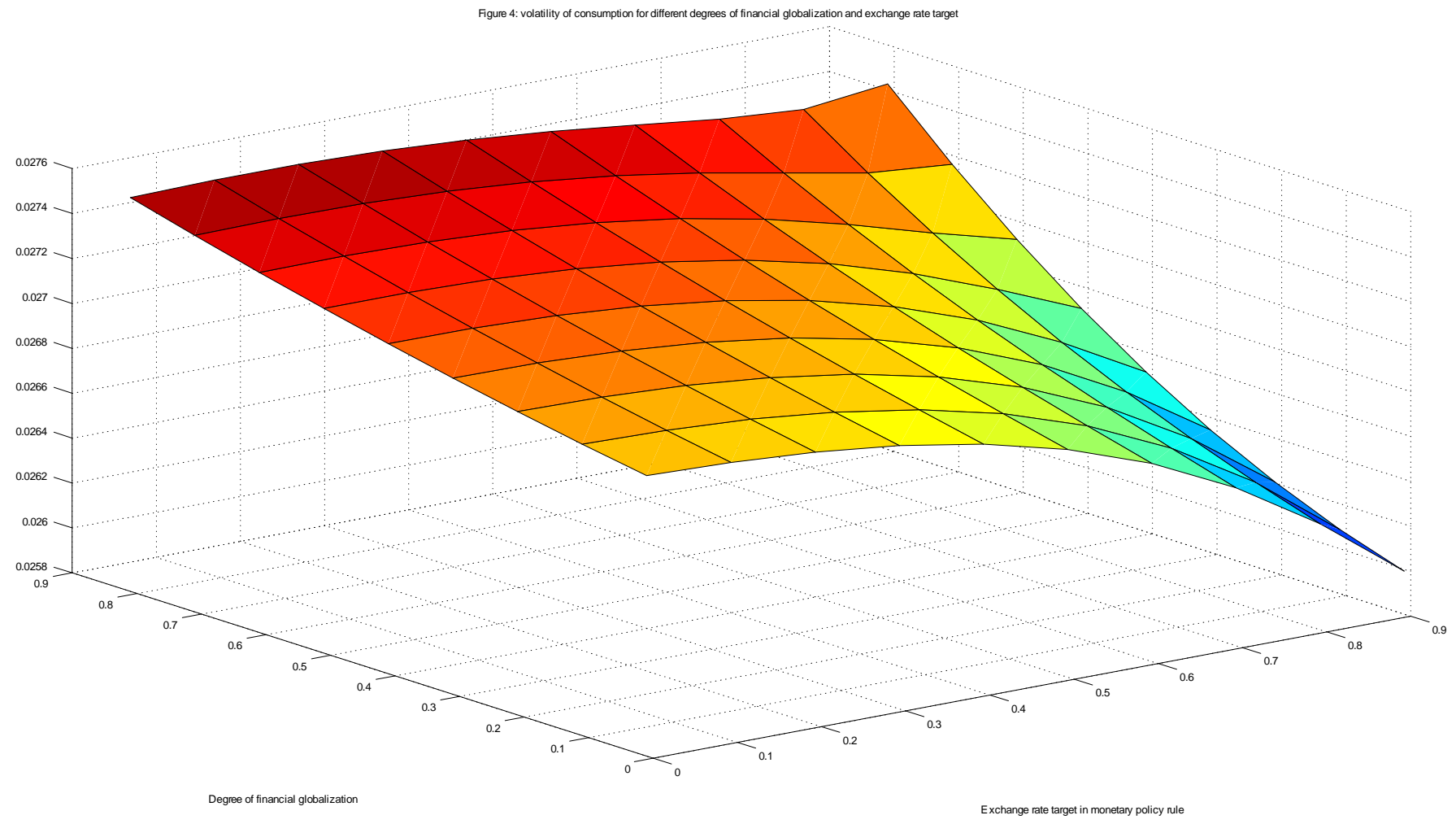




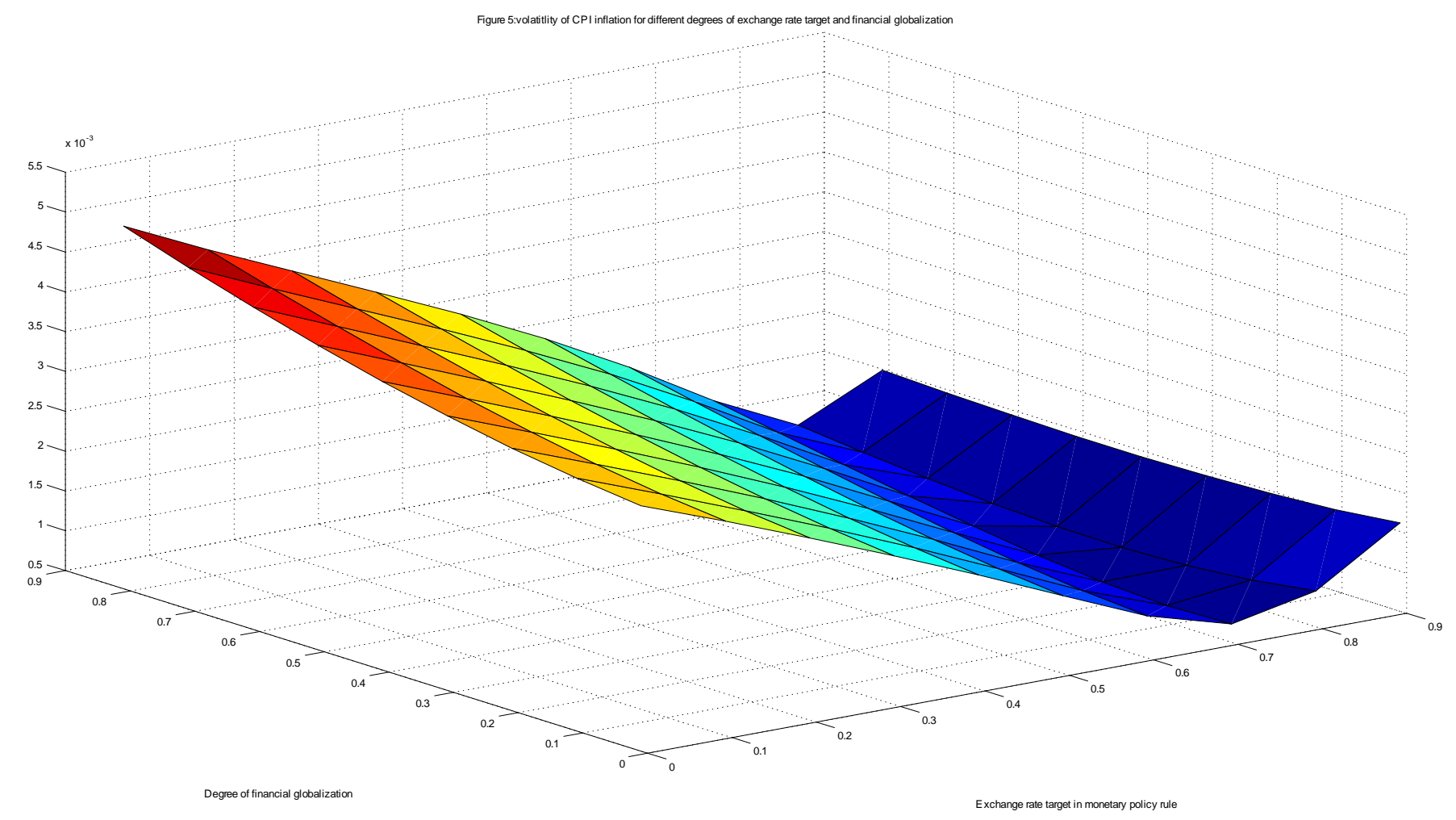




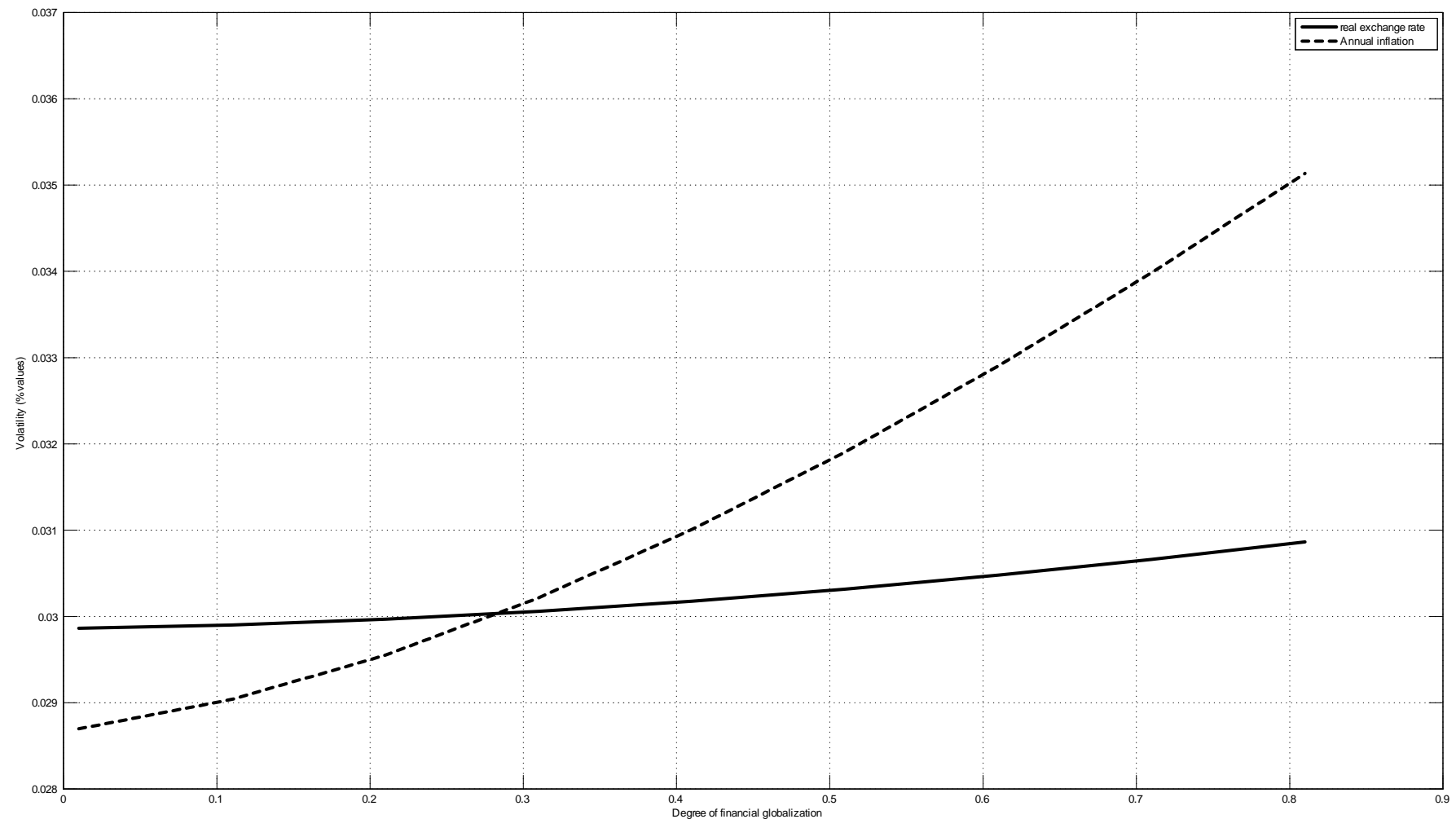

